\title{
DE LA GUERRA AL LLANTO: LAS EXEQUIAS DE LUIS XIV EN PALMA DE MALLORCA (1715-1716)
}

\author{
From War to Tears: The Funeral of Louis XIV \\ in Palma de Mallorca (1715-1716)
}

\author{
Miguel Gabriel Garí Pallicer ${ }^{1}$ \\ m.gari@uib.es \\ Universitat de les Illes Balears. España \\ Rafael Massanet Rodríguez \\ r.massanet.r@gmail.com \\ Universitat de les Illes Balears. España \\ Fecha de recepción: 10/10/2019 \\ Fecha de aceptación: 29/11/2019
}

RESUMEN: El presente texto tiene como objetivo el estudio de las exequias realizadas en Mallorca por la muerte del rey Luis XIV. Para ello, se contextualizan los vínculos entre la isla y Francia durante el reinado del rey Sol, se describen las actuaciones realizadas en memoria del abuelo del nuevo rey Felipe $V$ en la isla y se analiza el sermón fúnebre pronunciado en la catedral de Palma de Mallorca el 12 de diciembre de 1715.

Palabras clave: Luis XIV; Mallorca; sermones; exequias reales.

ABSTRACT: The aim of this text is the study of the funerals carried on in Mallorca in the occasion of the Louis XIV of France's death. For that reason, it will be contextualized the relations between the island and France during the Roi Soleil's reign, it will be describing the actions conducts in Mallorca in memory of the Philip V's grandfather and it will be analysed the funerary discourse read in Mallorca's cathedral in December of 1715.

Keywords: Louis XIV; Mallorca; homily; royal funerals.

1 Proyecto PRD201817 titulado "Conflicto e identidad en el Reino de Mallorca (siglos XIV-XVIII)" y financiado por la Dirección General de Política Universitaria e Investigación de la Consejería de Educación, Universidades e Investigación del Gobierno de las Islas Baleares. 
SUMARIO: 1. Introducción. 2. La Francia de Luis XIV en la Mallorca de finales del siglo XVII. 3. La Guerra de Sucesión. 4. Las honras fúnebres. 5. El predicador: Joan Antoni Ferrando, SI. 6. Organización y aparato de las exequias. 7. El libro de exequias. 8. El sermón del padre Ferrando. Estructura. 9. El rey a través del sermón. 10. Conclusiones. 11. Bibliografía.

\section{INTRODUCCIÓN}

La muerte de Luis XIV el día 1 de septiembre de 1715 es considerada una de las cesuras clave de la historia francesa y europea (Assaf, 1999; Cornette, 2015; Hersant, 2015; Macé, 2015). Su fallecimiento ponía fin a setenta y dos años de un reinado que los contemporáneos franceses consideraban como cénit civilizatorio y modelo de gobierno (Voltaire, 1954; Bonnet, 2015). Entre los principales méritos del rey se contaban el ensanche de las fronteras francesas tras las guerras contra Felipe IV y Carlos II, la consolidación en el trono español de su nieto Felipe $V$ y la conservación del territorio francés durante la Guerra de Sucesión (Álvarez López, 2007 y 2008; Bernardo Ares, 2008, pp. 165-190; 2015). Desde la perspectiva de una parte importante de los súbditos de la Monarquía Hispánica, el rey francés era un enemigo tradicional al que habían enfrentado durante los últimos setenta años. Tras el cambio dinástico de 1700, su imagen se reconvirtió en la del garante del cumplimiento del testamento de Carlos II y principal valedor de Felipe V (Burke, 1995, pp. 153-154). Esta transformación en la percepción de Luis XIV se había iniciado ya con las acciones de los embajadores franceses en la corte antes de la muerte de Carlos II. Los predicadores reales (Varela, 1990; Negredo, 2002; García Pérez, 2017 y 2019) no tardaron en sumarse a una campaña propagandística destinada a alabar a los Borbones. Otros individuos relacionados con la corte y las universidades continuarían esta labor (Borreguero Beltrán, 2003, pp. 97-100).

Por tanto, durante los primeros años del reinado de Felipe $V$ en España y, también, durante la Guerra de Sucesión (Bernardo Ares, 2011), la opinión pública sobre Luis XIV era positiva ${ }^{2}$. Esta valoración era compartida en determinados canales, más allá del partido cortesano que había apoyado la candidatura francesa al trono.

El presente texto pretende analizar una de las actuaciones llevadas a cabo a nivel local para operar este cambio en la percepción del Rey Sol y de la dinastía Borbón: las exequias celebradas en la catedral de Mallorca en memoria de Luis XIV. Para ello, se partirá de la relación del monarca francés con la isla durante el reinado de Carlos II y el contexto del final de la Guerra de Sucesión. A continuación, se analizará la descripción de los preparativos y ceremonias. Para finalizar, se estudiará el sermón fúnebre, predicado en la capital insular en memoria del rey cristianísimo.

2 Por ejemplo, en San Sebastián se le había comparado con el Padre Eterno. Martínez Gil, 2010, p. 308. En algunos elogios a Felipe V, escritos tras su coronación en 1700 , se nombra a Luis XIV como el Grande y se le representa como modelo y consejero de su nieto, como en el soneto del Marqués de Salmerón de 1701. Álvarez de Toledo, 1701. Otros ejemplos en García Cárcel, 2002, pp. 24-26. 


\section{LA FRANCIA DE LUIS XIV EN LA MALLORCA DE FINALES DEL SIGLO XVII}

Las relaciones entre Francia y el reino de Mallorca durante el reinado de Luis XIV fueron, como no podía ser de otra manera entre dos territorios fronterizos, muy estrechas. Durante la Guerra de los Treinta Años y las guerras de final de siglo, las operaciones de carácter militar se fueron sucediendo.

En el contexto de este enfrentamiento con Francia, la sociedad mallorquina creó una flota corsaria que constituyó una de las principales actividades económicas del territorio en el periodo (López Nadal, 1986; López Nadal y Morey Tous, 2018). Además, fue uno de los pilares en la guerra naval de la Monarquía Hispánica en el Mediterráneo. A su vez, las Baleares fueron utilizadas como plataforma de los ataques franceses contra $\mathrm{Argel}^{3}$. Desde la corte de Versalles se estudiaron con detenimiento las condiciones geográficas y las defensas de las islas (Espino López, 2008, 2010) con vistas a un posible ataque u ocupación (Morgat et al., 2010). El enfrentamiento no fue la única forma de relación de ambos territorios. El comercio fue, también, sostenido a pesar de los altibajos que acarrearon medidas derivadas de la guerra como la requisa de bienes o la expulsión de franceses del territorio (Alloza, 2005). A pesar de todo, el interés de las élites comerciales palmesanas y marsellesas por mantener un comercio tan fluido como permitieran las relaciones exteriores fue notorio (Deyá Bauzá, 2010). La presencia de marineros, capitanes y comerciantes franceses en MaIlorca fue constante durante los siglos XVII y XVIII (Bibiloni Amengual, 1995 y Vaquer Bennàsser, 2016). La conexión entre Marsella y Palma era, para Mallorca, uno de los enlaces más lucrativos. Se trataba del principal mercado para la exportación de aceite, y de una vía de acceso al producto más demandado por la isla, el trigo. Las guerras entre Luis XIV y la monarquía fueron un impedimento para el comercio mallorquín con Provenza, pero nunca un freno ${ }^{4}$. Para Mallorca, Francia era un aliado comercial y un enemigo político representado en la figura del rey cristianísimo.

${ }^{3}$ Hay mucha documentación referida a la presencia de armadas francesas fondeadas en las poblaciones de Pollença y Alcudia, al norte de la isla, para tomar refresco antes de iniciar acciones contra Argel. Por ejemplo: Archivo del Reino de Mallorca [ARM], Supl. 79, ff. 229v-247v.

4 Durante la Guerra de los Nueve Años el comercio entre Francia y los territorios mediterráneos de la monarquía continuaron. En 1690 el embajador de España en Génova avisaba del envío de naves genovesas con productos franceses (Archivo Histórico Nacional [AHN], Consejos, Libros 2534, f. 203r y ff. 205r-205v). En 1691, el Consejo de Aragón pedía a los virreyes que se vigilaran las sacas, pues los franceses estaban comprando cereal utilizando naves bajo bandera portuguesa. En 1694 se pedía a las autoridades que aseguraran que el trigo exportado por Mallorca no se dirigiera a Francia (Archivo de la Corona de Aragón [ACA], legs. 987, sf). En 1695 el ministro Pontchartrain concedía permiso a Honoré Rigord, magistrado de Marsella, para continuar con la exportación de manufacturas y trigo hacia Mallorca utilizando bandera genovesa (Archive Départementales de Boches du Rhône, IX B 3, f. 801). 


\section{LA GUERRA DE SUCESIÓN}

En su faceta de guerra civil, la población mallorquina se dividió entre los austracistas y felipistas (Montaner Alonso, 1990; Deyá Bauzá, 2007; Pascual Ramos, 2013; Morro Marcé, 2015). La posición respecto a Francia y los franceses fue una de las motivaciones de la elección de bando por parte de los mallorquines en la guerra (Montaner Alonso, 1990. Al igual que en Cataluña. Albareda, 2001). Ya antes de la propia guerra, los privilegios comerciales concedidos por el rey Felipe $\mathrm{V}$ a los mercaderes franceses motivaron fuertes críticas entre una parte de la población. La nueva situación provocaba preocupación por diversos motivos. Por un lado, la pérdida del corso contra los franceses como modus vivendi dificultó el comercio con el sur de Francia. La competencia la constituían los mercaderes galos asentados en la isla, quienes se beneficiaban de la venta de aceite a Marsella o la redistribución de productos americanos desde la Península y del Levante mediterráneo. Por otro lado, la reducción de los ingresos por el cobro de impuestos derivados de esta actividad era causa de una gran inquietud. Estas tensiones se palpaban en los distintos niveles de la vida comercial. Así, a pie de puerto, se llegó a enfrentamientos violentos que resultaron en el encarcelamiento de marineros franceses y la posterior protesta del cónsul francés. Finalmente, el enviado galo en la corte solicitó al rey la excarcelación. El rey emitió la orden al capitán general a quien indicaba que «se repongan en libertad dichos marineros para que reconozcan [los] franceses la buena inteligencia tan estrechamente establecida entre las dos naciones ${ }^{5}$. A su vez, Luis XIV intercedió ante su nieto para que ordenara al gobernador de Mallorca la devolución de los bienes del marsellés Antoine Surle. Este mercader actuaba en la isla desde, por lo menos, 1682 y había sido acusado de extraer moneda de la isla ${ }^{6}$. Ya en los primeros momentos de la guerra, cuando la isla permanecía bajo soberanía de Felipe $\mathrm{V}^{7}$, se produjo la detención de algunas personas por hablar contra el monarca ${ }^{8}$. La relación con los franceses suponía un motivo de intranquilidad en la corte.

Por ejemplo, en 1703 el rey escribía al capitán general de Mallorca para que le informara de las actividades de Baltasar Rossinyol Sagranada ${ }^{9}$, jurado primero de la ciudad, del ingeniero Martín Gil de Gaínza y del propio secretario del capitán general. Se sabía que estos individuos tenían «una conducta contra mis reales intereses a la unión que hai entre las dos coronas y al respeto y veneración que deven

${ }^{5}$ AHN, Consejos, Libros 2537, ff. 51v-52r.

${ }^{6} \mathrm{AHN}$, Consejos Libros 2537, f. 77v. El caso provocó la atención de las autoridades francesas, que trataron el caso ante Felipe V, por lo menos, entre 1700 y 1705.

7 Durante la guerra Mallorca estuvo bajo el gobierno de Felipe V entre 1702 y 1706 y bajo el archiduque Carlos entre 1706 y 1715.

${ }^{8}$ Campaner Fuertes, 1881, p. 61. Entre ellos, el obispo hizo detener a ocho sacerdotes.

${ }^{9}$ En el documento aparece como Baltasar Granada. 
al Rey Cristianísimo, mi abuelo y señor, hablando de SM sediciosamente ${ }^{10}$. Palma de Mallorca, tras ser el principal suministrador de Barcelona durante el asedio de 1714 , fue la última capital española en rendirse al ejército de Felipe $\mathrm{V}$ en el verano de 1715. La élite mallorquina filipista, que desde 1700 había visto con buenos ojos la nueva relación con Francia como una forma de integrarse plenamente en las redes comerciales marsellesas y que había tenido que huir o limitar sus actuaciones durante buena parte de la guerra por su posicionamiento, se preparaba en 1715 para tomar el mando y adaptarse a unos nuevos modelos político, basado en el de Luis XIV y que les permitiría una relación diferente con la corte, y económico, que tendría uno de sus pilares en la amistad con Francia. Tras la guerra y los acuerdos internacionales que asentaban en el trono a Felipe $\mathrm{V}$ la relación entre la isla y los franceses tuvo que cambiar (Bunes, 2018; Martín Corrales y López Nadal, 2018).

\section{LAS HONRAS FÚNEBRES}

Luis XIV moría en Versalles a las ocho de la mañana del 1 de septiembre de 1715. Acaba de finalizar la Guerra de Sucesión al trono español, tras la rendición de Mallorca el 2 de julio de 1715. La noticia fue conocida por su nieto en la corte de Madrid el 11 de septiembre por medio del Príncipe de Chelamar. Al día siguiente, se decretaron los lutos, ajustándose a los que se habían hecho al morir la reina ${ }^{11}$. Desde la corte se transmitió una real cédula a los gobernadores, arzobispos, obispos, catedrales, abades y ciudades de la monarquía, además de a los principales nobles.

El 23 de octubre de 1715, tras orden del rey del día 13 a la cámara de reales cartas, se redactaron en la corte distintas versiones para las autoridades civiles y eclesiásticas de los territorios de la Corona de Aragón ${ }^{12}$. Debido a la proximidad del final de la guerra, el envío de la noticia a Mallorca y Cataluña tuvo connotaciones que no se dieron en los reinos de Aragón y Valencia. Por considerarse intrusos o sede vacante, no se incluyeron como destinatarios a los obispos de algunas diócesis catalanas ni a la mallorquina. El vizcaíno Atanasio de Ezterripa y Traña-Jáuregui, obispo de Mallorca, había formado parte del apoyo a Carlos III $^{13}$. Tampoco se enviaron las nuevas a los nobles catalanes y mallorquines ni a las autoridades de las capitales del

10 AHN, Consejos, Libros 2537, ff. 97v-98.

11 La Gazeta de Madrid, 38, p. 152.

12 AHN, Consejos, Libros 2060, ff. 1r-8v.

13 AHN, Consejos, Libros 2060, f. 8r: «En cuio cumplimiento se han formado las reales cartas acostumbradas en semexantes casos para los obispos, cabildos, abades, priores, reales monasterios y provinciales de religiones de ese Principado de Cataluña, excepto para los obispos y abades intrusos que no han sido presentados por SM, a cuios cabildos y monasterios se les previene en las reales cartas que dispongan se executen las exequias en todas las iglesias de aquellas diócesis y abadías». 
Principado y de la isla de Mallorca. Sin embargo, sí las recibieron la nobleza principal de Valencia y Aragón. El motivo fue que no se había producido todavía la elección por parte del rey de los miembros de las instituciones locales ${ }^{14}$.

En Mallorca, los destinatarios de las cartas fueron el Capitán General, que recibió la misma misiva que el gobernador de Cataluña; el cabildo de la catedral, que recibió la misma carta que los cabildos de Barcelona, Tarragona, Solsona y Vich; el abad del monasterio de la Real y los provinciales de las órdenes religiosas ${ }^{15}$, quienes recibieron la misma noticia y petición que sus análogos del resto de la Corona de Aragón. Junto al capítulo catedralicio, se les informaba del sentimiento del rey ante la pérdida ${ }^{16}$ y se les ordenaba que en la catedral, iglesias, conventos y monasterios de su diócesis dieran muestra de compartir su dolor. También que se celebraran las honras, misas y oraciones que se hicieron en ocasión del fallecimiento de Mariana de Austria, del Delfín Luis y en el de María Luisa de Saboya ${ }^{17}$. La última notificación fue la enviada al Marqués de Castelo Rodrigo, capitán general de Cataluña, fechada tres días más tarde, el 26 de octubre. Se adjuntaba el pliego destinado al Marqués de Lede, capitán general de Mallorca, y se le indicaba que debía remitirlo a la isla ${ }^{18}$.

14 AHN, Consejos, Libros 2060, f. 8r-8v: «Y respecto de que aún no están puestos por SM sujetos para el gobierno político de las ciudades y villas de ese Principado, ha resuelto la Cámara que se suspendan las reales cartas, que es estilo también expedir en casos como este para dichas ciudades y villas pero que se prevenga a VE participe a estas la resolución de SM sobre las demostraciones en honrar lutos y exequias que hordena que se haga por dicho sr. Rey Cristianísimo, mandando VE a dichas ciudades y villas y también a los títulos que las executen como SM es servido mandar».

${ }^{15}$ Los franciscanos, agustinos y mínimos de Mallorca formaban una provincia independiente de la del resto de territorios de la corona de Aragón.

${ }^{16}$ El texto indicando el dolor del rey es común a todos los textos salvo el destinado a los capitanes generales: "La funesta quanto sensible noticia que he tenido de la muerte del sr. Rey Cristianísimo, mi abuelo, pasándole el no sr de esta a mexor vida me ha ocasionado el justo dolor y sentimiento que corresponde a tan incomparable pérdida en que por el amor de mis vasallos los considero igualmente en el sentimiento» (AHN, Consejos, Libros 2060, f. 5r).

${ }^{17}$ En esta parte se modificó el texto para adaptarlo al receptor: "os he querido dar noticia y rogaros y encargaros (como lo hago) roguéis a Dios por su alma y haciendo en esa iglesia (catedral) las honras y diciendo misas y otros sufragios y oraciones que en tales casos se acostumbra, las mismas que se executaron por el fallecimiento de la srma. reina $D^{a}$ Mariana de Austria, a que se arreglaron las del serenísimo Delphín, mi padre, y las de la srma. Reina Dạ María Luisa de Savoia, mi mujer y dispongáis lo mismo en todas las iglesias de esa diócesis. Que de ello me daré por mui servido. Del Buen Retiro a 23 de octubre de 1715» (AHN, Consejos, Libros 2060, f. 5r).

18 «En el pliego adjunto para el Marqués de Lede van las órdenes para Mallorca sobre las honras, lutos y exequias que manda SM se hagan por el sr. Rey Cristianísimo. Y a efecto de que se logre que dicho pliego llegue con seguridad a aquella isla, le remito a mano de VE para que se sirva disponer su aviso en la primera ocasión segura que se ofreciere para dicho reino de Mallorca. $Y$ de su reino espero se servirá darme $V E$, cuia vida dese que Dios dilate años. 26 octubre 1715. Al excmo. sr. Príncipe Pío, marqués de Castel Rodrigo» (AHN, Consejos, Libros 2060, f. 8v). 
Por el momento, no conocemos el contenido de esos pliegos, pero no debían diferir en demasía con los que recibiría el gobernador del Principado ${ }^{19}$. Se les informaba del envío de cartas a los territorios de la Corona de Aragón, ordenándoles que vigilaran la ejecución de las exequias, que informaran de las órdenes al obispo y a las ciudades y villas y mandando que se practicara en todas lo mismo.

La emisión de la noticia y de la orden de celebrar exequias inmediatas en todos los rincones de la monarquía responde a tres motivos: a la necesidad de asentar a Felipe V y a la dinastía en el trono; a divulgar sus principios de gobierno; y a crearle una imagen que le hiciera conocido y aceptable para toda la población (Serrano Martín, 2014). Las cartas también muestran la voluntad regia de recibir muestras de adhesión de sus súbditos. La celebración de unas exequias era una gran oportunidad para lograr esos objetivos, pues conjugaba diversos medios de propaganda y comunicación escrita y audiovisual a través de un programa iconológico e ideológico definido desde la corte por el monarca y sus asesores (Pascual Chenel, 2014).

A su vez, las exequias se presentaron a las élites locales como un medio para congraciarse con el nuevo poder y demostrar su adhesión (León Pérez, 2010, p. 96). Desde el momento posterior a la rendición de Mallorca a las tropas borbónicas lideradas por el caballero D'Asphelt en el verano de 1715, las autoridades trataron de negociar con el poder central y sus representantes en el reino para tratar de mantener cierta cuota del poder político e institucional ${ }^{20}$. Junto al envío de embajadas a la corte o peticiones al gobernador, la celebración de ceremonias se convirtió en otro instrumento con el que agradar al gobernador del reino, el flamenco Jean François de Bette, Marqués de Lede, y mediante a este al propio Felipe $\mathrm{V}$, y mostrar la adhesión a la nueva dinastía. Durante la inmediata posguerra, entre noviembre de 1715 y octubre de 1716, los jurados del reino pusieron mucho empeño en demostraciones de aceptación del nuevo mandato con las exequias de Luis XIV el 12 de diciembre; la celebración del cumpleaños del propio rey el 19 de diciembre; un Te Deum en la catedral por el nacimiento del príncipe Carlos Sebastián el día 15 de febrero de 1716; una ceremonia en mayo de ese año para celebrar el día de San Felipe; y, finalmente, el aniversario del Príncipe de Asturias en octubre ${ }^{21}$. Una muestra de la importancia dada a todas estas ceremonias fue la facilidad con la que el Marqués de Lede concedió su placet para dedicarles el uso de más de 1.600 libras de fondos de la administración $\left.\right|_{\text {local }}{ }^{22}$.

19 AHN, Consejos, Libros 2060, ff. 7v-8v.

20 Santamaría Arández, 1989; Pascual Ramos, 2016; Deyá Bauzá, 2018.

21 Archivo Capitular de Mallorca [ACM], Sacristía 1397, ff. 41v-42r, 43r y 46; ARM, Suplicaciones 84, ff. 7v, 11v, 21r y 46r; Campaner Fuertes, 1881, p. 508-509.

${ }^{22}$ ARM, Suplicaciones 84 , ff. 7v, 11v, 21r y $46 r$. 
1. Gastos de demostraciones hacia los Borbones. 1715-1716

Fecha $^{23}$ Celebración

Concepto

Gasto

12/12/1715 Exequias de Luis XIV

Exequias

1.400 libras

19/12/1715 Cumpleaños Felipe V

Cera, música, aceite y otros

100 libras

12/02/1716 Nacimiento del príncipe

Luminarias

486 libras

22/05/1716 Fiesta de San Felipe

Fiesta

65 libras

3/10/1716 Cumpleaños Príncipe de Asturias

Celebración

84 libras, 6

sueldos, 1

dinero

Tras recibir la noticia, las autoridades civiles y religiosas se prepararon para celebrar las exequias que exigía un acontecimiento que tocaba a una figura clave en la vida del retornado rey, a pesar de los conflictos entre ambos en algunos momentos de la guerra (Albareda, 2000, pp. 22-34). En cada una de las capitales de la monarquía se realizaron unas exequias honrando al que una vez fuera el principal enemigo de la corona. Por ello, en toda la monarquía se celebraron y tenemos noticias de la exaltación de la figura de Luis XIV en la península; Madrid (Castejón, 1716 y Fernández Pacheco, 1717), Granada (Martínez Ramos, 2011, p. 141), Málaga (Casal Montenegro, 1716), Valencia ${ }^{24}$, Aragón (Serrano Martín, 2014) o Mallorca, así como también en Nueva España ${ }^{25}$ y en las islas Filipinas ${ }^{26}$. Además, la nueva fue respondida por los principales nobles españoles ${ }^{27}$ y franceses ${ }^{28}$.

En el caso mallorquín se han conservado dos descripciones de las exequias con sus sermones. Uno leído en la parroquial de Alcudia y otro en la catedral de Palma. La primera fue impartida por el jesuita Bartolomé Antonio Fullana con el título "Oración fúnebre en las solemnísimas exequias con que la fidelísima ciudad de Alcudia en el Reino de Mallorca lloró la muerte del Sol de la Francia, el Insigne rey Luis XIV» (Ferrando, 1716). El discurso en la capital lo leyó el también jesuita Juan Antonio Ferrando, con el título: «Elogio fúnebre a las gloriosas memorias del Serenísimo

${ }^{23}$ Aprobación del gasto. Salvo en las exequias de Luis XIV en el que la fecha corresponde a la celebración.

${ }^{24}$ AHN, Nobleza, Osuna, CT 136, D 61.

25 Bracamonte, 1717; Ortega Gato, 1953, p. 17; Mínguez, 1994; Mínguez, 2016, pp. 418419; Escamilla González, 2011, pp. 139-140.

${ }^{26}$ Luengo, 2012, p. 224. El gobernador de Filipinas, Fernando Manuel de Bustillo Bustamante y Rueda, envió en 1718 un informe completo sobre las exequias celebradas en Manila en honor a Luis XIV. Archivo General de Indias [AGI], Filipinas 137, n. 30.

27 Carta del IX Duque de Béjar: AHN, Nobleza, Osuna C 3517.

${ }^{28}$ Entre otros, enviaron cartas a Felipe $V$ con motivo de la muerte de su abuelo el Marqués de Bauffremont, el Duque de Berwick, el Duque de Gramont, el Duque de Harcourt, el Mariscal de Tessé o el Marqués de Thoy. AHN, Estado, Legajos 123-143. 
Señor Luis XIV el grande, rey cristianísimo de Francia. En las reales funerales honras que en obsequio de SM celebró la ciudad y reino de Mallorca el día 12 de diciembre del año 1715» (Fullana, 1716).

\section{EL PREDICADOR: JOAN ANTONI FERRANDO, SI}

En ambos casos, la predicación fue obra de dos jesuitas, una orden cuya postura en el transcurso de la guerra fue ambigua, pues desde Roma se trató de mantener la ascendencia en las cortes de ambos contendientes (Bada, 2007; Alabrús, 2014, p. 229), aunque en el escenario peninsular de la guerra, salvo excepciones como el reino de Aragón, la orden se situó del lado borbónico (Pérez Picazo, vol. 1, 1966, p. 66). A este papel en la guerra, se ha de unir la inclinación del rey por los jesuitas. Pueden rastrearse una serie de aspectos, como que su confesor durante la guerra fuera el jesuita Pierre Robinet (Egido López, 2004, p. 235; Martínez Peñas, 2007, p. 558), figura clave en algunas actuaciones político-religiosas de importancia, como la misión jesuita en la ciudad de Játiva (Burrieza, 1998, pp. 86-96), o la labor de los jesuitas en la corte francesa donde se había criado Felipe V (Burke, 1995, p. 103). Por ello, no es de extrañar que los sermones en la capital durante esta importante circunstancia se concedieran a jesuitas. En Madrid, el elogio fúnebre dedicado a Luis XIV en la Encarnación fue impartido por el padre Agustín de Castejón, predicador en la corte del rey Felipe $\mathrm{V}^{29}$. En 1711 se le encargó la predica de las honras por las muertes del Delfín de Francia Luis y de su mujer María Adelaida de Saboya, padre y madre del rey, así como la de María Luisa de Saboya, la primera esposa de Felipe $\mathrm{V}$, en mayo de $1714^{30}$. El sermón fúnebre en las exequias organizadas por la villa de Madrid en la iglesia de Santo Domingo fue declamado por el también jesuita Manuel Antonio de Frías (León Pérez, 2010, pp. 282-284). En Zaragoza, el encargado de componer las exequias fue el también jesuita José Andosilla (Andosilla, 1716).

La casuística en la elección del orador es muy variada y hay casos donde el elogio fúnebre fue predicado por frailes de otras órdenes. En Ávila, fue el canónigo Zúñiga (Zúñiga Ribera, 1716); en Calatayud, el fraile mercedario Antonio Salvador Gilabert (Castellanos Losada, 1865, p. 400); en Carmona, el carmelita fray Juan de la Presentación (1716); en Málaga, fue el trinitario y canónigo magistral Juan Agustín Casal y Montenegro (1716); o en la capilla real de la Universidad de Salamanca, el benedictino fray Juan Antonio de Haro (1716). En América conocemos las exequias predicadas por el arzobispo José Pérez de Lanciego Eguilaz, benedictino navarro, en la ciudad de México (Bracamonte, 1717) y las del párroco José de Alcalá Guiribari

29 Castejón, 1716.

30 Las exequias madrileñas por los Borbones se han estudiado en León Pérez, 2010. 
en Valladolid de Michoacán, de quien no conocemos su adscripción a ninguna orden (Alcalá Guiribari, 1717).

En Mallorca, los sermones de las dos principales poblaciones, Palma y Alcudia, fueron leídos por destacados miembros de la orden jesuita ${ }^{31}$, algo que no es de extrañar dada la firme apuesta de la Compañía en la isla a favor de Felipe V (Juan Vidal, 2014, pp. 172 y 184). En la Seo de Mallorca el encargado de realizar el sermón fue el padre Juan Antonio Ferrando (1675-1744) (Ramis Barceló, 2014, p. 414; Díaz Díaz, 1988, p. 199), jesuita, doctor en teología, maestro de filosofía en el Colegio de San Martín de Girona, donde estudió parte de su carrera eclesiástica, aunque realizó la tercera probación en el colegio de San Ignacio de Pollença, en Mallorca. Desde, por lo menos, 1693, ocupó cargos en el convento jesuita de Montesión de Palma. Ese año se le nombraba maestro de vísperas de teología, encargado del acto de contrición y examinador de los hermanos ${ }^{32}$. Posteriormente, ejerció otros oficios como los de maestro de vísperas y corrector de acentos en 1695 y prefecto de las escuelas menores entre 1695 y 1699, año en el que, también, se encargó de las pláticas a los coadjutores ${ }^{33}$. Antes de la guerra, en 1703, era viceprefecto de estudios mayores, examinador de los hermanos, revisor de vestuarios y consultor ${ }^{34}$. Fuera del convento ejerció como catedrático, primero de vísperas y después de prima por la opinión suarística en la Universidad Luliana de Mallorca, como examinador sinodal del obispado de Mallorca y como calificador de la Inquisición en el reino de Mallorca, por lo que asistió al segundo gran auto de fe contra los conversos mallorquines en 1691 (Garau, 1691, f. 114), y del Santo Tribunal de Aragón ${ }^{35}$.

Además de las honras fúnebres dedicadas a Luis XIV, fue autor de otros sermones y prédicas. Ya en su etapa de formación, durante la tercera probación en el colegio de Pollença de Mallorca, predicó en esa parroquia y en algunas vecinas (Ferrer Flórez, 2004, pp. 56, 59, 60). Junto a las honras fúnebres, también se imprimió el «Sermón del Bto. Raimundo Lulio predicado en su fiesta anual en la iglesia del convento de San Francisco de Asís», impreso en Palma en 1695 (Bover, 1868, pp. 278-279). El hecho de que le encargaran este sermón indica que era un predicador solvente y al que se acudía en ocasiones importantes, como era la festividad de Ramón Llull organizada por la orden franciscana. Se conocen, también, las obras «Pláticas morales» de 1701, un tratado teológico y tres cursos entre 1694 y $1707^{36}$.

31 El trabajo más completo por el momento sobre la orden jesuita en Palma es Obrador Vidal, 2011.

32 AHN, Clero Jesuitas Libro 747, f. 281v.

33 AHN, Clero Jesuitas Libro 747, 286v, 305r.

34 AHN, Clero Jesuitas Libro 747, f. 314r.

35 Sobre la carrera universitaria de Ferrando vid. Ramis y Cassanyes, 2014, p. 62 y p. 68; Ramis Barceló, 2014, pp. 415 y 424.

36 El «Tractatus sive opusculum theologicum scholasticum de simplicitate Dei seu 
Durante su trayectoria, asesoró a las autoridades políticas locales en muchas ocasiones sobre temas relativos a la Universidad Literaria y al culto luliano (Pérez Martínez, 1985, p. 335; Montaner et al., 2006, p. 193).

La postura del predicador durante la guerra fue la de activo proborbónico (Cassanyes Roig, 2017, p. 188). El Padre Ferrando, ya antes de la contienda, se mostró favorable al rey Felipe $\mathrm{V}$, como muestra su participación en la delación del también jesuita mallorquín Ignaci Fiol, a quien en 1706 se le atribuyeron unas profecías apócrifas que injuriaban a Carlos II y promovían la sedición contra Felipe V (Llabrés, 1935, p. 74). Al año siguiente, en 1707, tras la ocupación austracista y por orden real, fue expulsado de la isla junto con otros seis jesuitas ${ }^{37}$. Para ello, se les embarcó en un navío maltés, en principio con dirección a Milán, que llegó a Cataluña por culpa de una tormenta, desplazándose después hasta Aragón (Ferrer Flórez, 2004, p. 94). Desde allí, llegó a Italia y, probablemente, a Malta, donde era obispo el mallorquín Jaume Cànaves March, permaneciendo fuera de Mallorca durante ocho años hasta el final de la guerra ${ }^{38}$. Durante su exilio, coincidió con personajes ilustres como el padre Francisco de la Motte o el mallorquín Bartolomé Rull, quien había sido su alumno y llegaría a ser Gran Prior y obispo de Malta (Oliver Moragues, 1997, p. 12).

A su vuelta al reino en 1715 , las autoridades locales le propusieron hacer la oración fúnebre en memoria de Luis XIV en la catedral, un discurso de gran relevancia dado el tema y el contexto. El doctor Josep Bassa, abogado fiscal del real patrimonio, al elaborar uno de los pareceres sobre el discurso de Ferrando, describió su elección como acertada por su sabiduría, fidelidad y afecto al servicio real (Ferrando, 1716, ff. 28-29). En noviembre de ese año, se le concedieron los cargos de prefecto de estudios mayores, de confesor y revisor de vestuario en el colegio

Distinctione et Idemptitate Predicatorum Divinorum inter se», de 1694 se encuentra en Real Academia de la Historia [RAH], 9/3363, 1. Allí, también están depositadas dos copias manuscritas del curso "Tractatus theologicus scholasticus de profundissimo Trinitatis mysterio in primam partem Angelici Doctoris D. Thomae a quaest. 27 ad 45», una de 1694 y otra de 1707 (RAH, $9 / 3038$ y RAH, 3363, 2). Hay otro manuscrito docente de un curso del p. Ferrando en la Biblioteca Pública de Mallorca [BPM], Ms. 287.

${ }^{37}$ El 16 de octubre de 1707 el Colegio de Montesión pagaba 469 libras, 6 sueldos y 8 dineros por provisiones y fletes de embarcar en un navío maltés a los padres Diego García, rector del colegio, a Jordi Fortuny, a Joan Antoni Ferrando, Gabriel Coll, Albert Pueyo y a los hermanos Jaume Sierra y Vicens Crespí que por orden de Carlos III debían ser trasladados a Milán. Además, les entregaron ropas de paño catalán y de Pollença por valor de 91 libras, 17 sueldos y 6 dineros. ARM, Clero 401.

38 ARM, EU 89, ff. 225v-226r; Ramis Barceló, 2018, p.365. 
jesuita de Montesión ${ }^{39}$. Poco después, en febrero de 1716, pidió la jubilación como catedrático universitario ${ }^{40}$.

Hasta su muerte, Ferrando siguió con su labor teologal, continuó como miembro del Santo Oficio, se relacionó con la élite local y ocupó diversos oficios en el convento jesuita. En 1721 publicó una delación de unas conclusiones lulianas para la Inquisición (Ramis Barceló, 2013, p. 134) y asesoró al ayuntamiento en algunos temas, estando presente en la junta de regidores y teólogos que debatió el nombramiento de Santa Bárbara como patrona de Palma en 1727 (Fajarnés, 1897, p. 222). A pesar de su reconocido filipismo, en 1728 aparece como albacea, junto a otros jesuitas, en el último testamento del Marqués de la Torre, Nicolau Truyols Dameto, destacado austracista durante la guerra (Pascual Ramos, 2013, p. 235). Tras su vuelta a Mallorca y hasta su muerte, siguió ocupando cargos en la comunidad jesuita palmesana. En 1722 era prefecto de estudios mayores, prefecto de espíritu, consultor, confesor y examinador de hermanos del convento y colegio de Montesión ${ }^{41}$. Entre 1726 y 1738 fue nombrado prefecto de espíritu y admonitor, daba los ejercicios de los hermanos y continuó como consultor y confesor ${ }^{42}$. En 1743, un año antes de fallecer, Ferrando conservaba el oficio de prefecto de espíritu, cargo relacionado con la formación espiritual y la confirmación de las vocaciones de los hermanos más jóvenes, los estudiantes y coadjutores ${ }^{43}$.

Por lo tanto, dadas la relación de la orden con el nuevo rey Borbón, la conducta del padre Ferrando durante la guerra y su posición en el convento jesuita, la Inquisición y la Universidad Luliana, su elección como predicador en las honras fúnebres de Luis XIV no resultó ni polémica ni extraña ${ }^{44}$.

\section{ORGANIZACIÓN Y APARATO DE LAS EXEQUIAS}

El libro de las exequias pronunciadas en Palma de Mallorca, que incluye el sermón del padre Ferrando, se inicia con una portada en la que destaca que los funerales se habían hecho a cargo de las autoridades locales, lo que se remarca con el añadido de la imagen del escudo de la ciudad, y continúa con una descripción de las funerarias. Las primeras palabras se dirigen a loar la figura de Luis XIV a partir del sobrenombre, oficial desde 1671-1672 (Burke, 1995, p. 76), de "el Grande», recalcando su parentesco con Felipe V. Se exaltan sus acciones, que le convertían en

\footnotetext{
${ }^{39}$ AHN, Clero Jesuitas Libro 747, f. 343v.

${ }^{40}$ ARM, EU 89, ff. 225v-226.

${ }^{41} \mathrm{AHN}$, Clero Jesuitas Libro 747, ff. 354r y 354v.

42 AHN, Clero Jesuitas Libro 748, ff. 18v, 34r, 46v, 62r y $79 r$.

${ }^{43}$ AHN, Clero Jesuitas Libro 748, f. 112r.

${ }^{44}$ Sobre la elección de predicadores vid. Burrieza Sánchez, 2004 y Negredo del Cerro, 2012.
} 
una suerte de héroe clásico ${ }^{45}$ y se resalta su muerte como una pérdida para Francia, pero, también, para España y el catolicismo. Tras el marco inicial, se alaba el gobierno establecido en la isla por el Marqués de Lede como lugarteniente de Felipe V, expresando el deseo de su continuidad y destacando que había sido capaz de aliviar las tensiones internas ${ }^{46}$.

Al igual que en este fragmento, en las descripciones de los preparativos y de las funciones religiosas, el objetivo principal es destacar la participación de todas las fuerzas vivas en un acto que honra la nueva dinastía demostrando su adhesión al gobierno borbónico. La narración del momento en que se notificó a los jurados y a la nobleza mallorquina trata de transmitir el sentimiento de luto de la élite local. Se resalta que, a pesar de la falta de fondos destinados a las ceremonias debido al cumplimiento de decretos reales ${ }^{47}$, se trataría de hacer la ceremonia más suntuosa y con mayor aparato que se hubiera hecho nunca en la ciudad. La justificación para honrar la memoria de Luis XIV, antiguo enemigo, fue la ayuda que brindó, aportando sus tropas a las de Felipe V, para recuperar la isla de Mallorca. Los jurados recordaban en el texto que la expedición comandada por el caballero d'Asphelt era la última de las victorias militares del Rey Sol, su última palma (Ferrando, 1716, f. 5).

Tras la justificación, los jurados describen los primeros pasos de la organización del funeral, fijando el día, el 12 de diciembre de 1715, y el lugar, la catedral de MaIlorca. Una representación de las élites locales conformada por doce caballeros, que incluía miembros del estamento ciudadano, liderada por Joan Despuig, Conde de Montenegro y Montoro, fue a notificar la decisión a las principales autoridades del reino que incluían al comandante general, a los miembros de la Real Audiencia, al obispo, al cabildo de la catedral y a los inquisidores.

Como en otras ciudades y momentos anteriores ${ }^{48}$, desde que se conoció la noticia se trató de crear un clima de recogimiento y de homenaje hacia la figura del difunto rey ${ }^{49}$. Así, se compraron cortinas negras para enlutar las puertas de la sede del poder local y la casa del Sindicat de Fora, institución que reunía a las élites de los municipios mallorquines, donde se colocaron el día 27 de noviembre ${ }^{50}$. También,

45 «Siendo casi preciso que un Monarca tan grande dexasse de ser hombre en la muerte para que nos acabáramos de persuadir que en la realidad no había sido más que un hombre en la vida» (Ferrando, 1716, f. 1).

46 «Con su discretísimo feliz gobierno (...) ha sabido dulcemente grangear los ánimos y llegado a establecer su amable imperio» (Ferrando, 1716, f.4).

${ }^{47}$ Hace referencia a los privilegios de 1600 y 1614 concedidos por Felipe III que limitaban los usos de los fondos de la administración local.

48 Sobre exequias reales en Palma en el siglo XV, vid. Barceló Crespí, 2018.

49 Por ejemplo, en Valencia se prohibieron las corridas de toros y se repartieron limosnas a los pobres. AHN, Nobleza, Osuna, CT 136, f.1.

${ }^{50}$ Campaner Fuertes, 1881, p. 506; ARM, AH 6155, sf. 
por petición de los jurados, se hicieron resonar las campanas de la catedral tres veces cada noche durante nueve días ${ }^{51}$. Los canónigos trataron de persuadir al obispo para complementarlo con el resonar de las campanas de las parroquias y conventos y la impartición de cien misas, repartidas en nueve días, en la capilla de San Pedro de la catedral ${ }^{52}$.

En el interés por exaltar a Luis XIV, cada ciudad trató de hacer uso de la imagen a través de la construcción de túmulos funerarios en su honor ${ }^{53}$. El día 22 de noviembre, los jurados del reino, junto al canónigo Miquel Ballester y la junta de la Real Consignación, decidieron hacer todos los gastos posibles en las exequias en memoria del rey francés ${ }^{54}$, a pesar la mala situación económica de las instituciones tras la guerra (Deyá Bauzá, 2014).

En la documentación generada tanto por el capítulo catedralicio como por las autoridades locales la principal preocupación fue el engalanamiento de la catedral, a partir del diseño de la iluminación, la decoración, la escenografía, la distribución de los asistentes, la elección del predicador y la construcción del túmulo. En el impreso palmesano del sermón, se incluyó una representación gráfica y una descripción del túmulo en un folio desplegable ${ }^{55}$. El túmulo, obra del artista milanés Giuseppe Dardanone (Llabrés, 1993), fue valorado en 740 libras y ejecutado entre el 26 de noviembre y el 11 de diciembre ${ }^{56}$. Tenía 160 palmos de altura y estaba cubierto por tela, friseta o bayeta, negra y candeleros. La iconografía representada constaba de elementos clásicos de este tipo de monumentos (Varela, 1990, pp. 109-111). Destaca una vanitas, una corona y ocho banderas con el escudo de la flor de lis de la familia Borbón ${ }^{57}$. En la descripción, así como en la documentación económica generada por los jurados, el aspecto que más se acentúa es el valor de las telas utilizadas en la decoración del túmulo.

Una parte importante de la organización del funeral fue compartida entre los jurados y caballeros de la ciudad y los canónigos de la catedral. La colaboración del

${ }^{51}$ El 8 de enero de 1716 el capítulo catedralicio pagó diez libras a cinco escolanos por tocar las campanas cada anochecer. ACM, Sacristía 1397, f. 91r.

52 ACM, AC, 1643, f. 403r-403v.

53 Soto, 1989; Allo Manero y Esteban Llorente, 2004; Rodríguez Moya, 2015.

${ }^{54}$ ARM, EU 89, f. 217.

55 La imagen ha sido reproducida en Sebastián López, 1973; Bosch Juan, 2003 y Rodríguez Moya, 2015.

${ }^{56}$ ARM, EU 89, f. 217v.

57 La parquedad iconográfica del túmulo palmesano se contrapone a la riqueza del zaragozano. Andosilla, 1716, ff. 53-60. El túmulo de la catedral mallorquina no contaba con inscripciones como en el caso del colocado en la catedral de Málaga, en el que se adjuntaron epitafios, sonetos y jeroglíficos. Casal Montenegro, 1716, ff. 31-38. 
capítulo catedralicio fue total ${ }^{58}$. El propio cabildo había enviado una misiva a la corte poco después de la toma borbónica de la isla. Así, el 20 de septiembre de 1715 el canónigo Gabriel de Salas escribió al resto del capítulo y al obispo informando que, con el padrinazgo del Caballero D’Asphelt, había podido besar la mano del rey, la reina y el príncipe y transmitir la adhesión del cabildo. El 8 de octubre el gobernador agradecía en nombre del rey la carta que habían enviado ${ }^{59}$. Cuando el 13 de noviembre el capítulo leyó la carta enviada por el monarca, fechada el 23 de octubre, en que se les informaba del fallecimiento de su abuelo, se enviaron dos canónigos hasta el palacio del gobernador para, como pedía el propio rey, ponerse a su disposición para cualquier acto que se realizara. En la carta real se indicaba que la catedral debía hacer las mismas honras y misas que se habían hecho en memoria de Mariana de Austria, del Delfín Luis, padre de Felipe V, y de su esposa María Luisa de Saboya ${ }^{60}$. Dos días después, se decidió enviar al gobernador una atestación con una descripción de las ceremonias dedicadas a la reina Mariana de Austria en $1696^{61}$. Cuando el 27 y el 29 de noviembre los jurados fueron al capítulo de los canónigos para solicitar su colaboración en los preparativos y colocar el túmulo en la Seo, la aceptación fue inmediata $^{62}$. El 8 de diciembre fue el propio gobernador quien sugirió una modificación. En concreto, pidió al obispo y al capítulo celebrar en la catedral las misas por el alma del rey Luis XIV, que estaban previstas realizarse en las parroquias palmesanas. Los canónigos ordenaron a Jaume Joan, sacerdote maestro de ceremonias de la catedral, que señalara una capilla de la Seo para cada parroquia ${ }^{63}$. El día 10 de diciembre, los canónigos diseñaron parte de la escenografía de la ceremonia religiosa eligiendo a los canónigos que asistirían al obispo en las honras ${ }^{64}$.

La víspera del funeral, el día 11 de diciembre se iniciaron los actos. Por la mañana, los doce caballeros, todos destacados filipistas ${ }^{65}$, hicieron las visitas protocolarias a las autoridades de la ciudad para invitarles oficialmente a las honras fúnebres. Para ello, visitaron al gobernador, al obispo, los canónigos y a los inquisidores ${ }^{66}$. Por

${ }^{58}$ Sobre el capítulo catedralicio de la catedral de Mallorca en este periodo, vid. García Pérez, 2014.

${ }^{59} \mathrm{ACM}, \mathrm{AC} 1643$, f. 392r, 392v y 394.

${ }^{60}$ ACM, AC 1643, f. 399r.

${ }^{61}$ ACM, AC 1643, f.400r.

62 ACM, AC 1643, f.403r-404r.

${ }^{63}$ ACM, AC 1643, f. 406v.

${ }^{64}$ ACM, AC 1643, f. 407r. Como asistente se eligió al canónigo Togores, en el evangelio a Sureda, en la epístola a Llorens y para las nueve lecciones al sacristán Togores, mayor.

${ }^{65}$ Sus nombres están recogidos en Ferrando, 1716, f.5.

${ }^{66}$ En la visita al cabildo catedralicio los caballeros anunciaron su llegada por medio del síndico de la ciudad $y$, después, hicieron una entrada a la sala capitular donde entraron acompañados por los canónigos ya vestidos de duelo. ACM, AC 1643, 407v-408r. 
la tarde una comitiva de catorce oficiales a caballo, vestidos con capuces de luto, desfiló por la ciudad. Iban acompañados por tamborileros pregonando la nueva de la defunción de Luis XIV, a la vez que solicitaban sufragios por su alma (Ferrando, 1716, f. 6). El final del acto fue la asistencia a los maitines de finados en la catedral. La procesión de la élite local, el sonido de los tambores, las cortinas negras en los principales edificios civiles con las flores de lis, el repique de las campanas de todas las iglesias de la ciudad y la decoración de la catedral con la bayeta negra y el gran túmulo, en el que se gastaron 92 antorchas, crearon un clima propicio para que toda la ciudad sintiera como propia la pérdida del rey de Francia y para la celebración de las exequias el día siguiente.

El día 12 de diciembre de 1715 tuvieron lugar las exequias. A las ocho y media de la mañana las autoridades locales salieron hacia la catedral, acompañados por tamborileros, oficiales, maceros y representantes de los gremios de la ciudad, todos enlutados con capuces o túnicas negras y portando una gran cantidad de cirios y candelas ${ }^{67}$. La comitiva, encabezada por los jurados y los caballeros, se dirigió al palacio real de la Almudaina, donde les esperaba el Marqués de Lede junto al baile Ramon de Puigdorfila y el veguer Jordi Fortuny (Ferrando, 1716, f. 9). Una vez reunidos, todo el séquito se dirigió a la catedral.

El mismo día el custos de la Seo se encargó, junto al sastre Guillem Julià, de acabar la escenografía del acto ${ }^{68}$. Hizo colocar los asientos de los oficiantes y autoridades, cubrió con bayeta negra los bancos, el dosel donde se situaba el obispo, las tronas, la tumba del rey Jaime II y buena parte del presbiterio y del altar mayor, repartió candelas y velas entre los asistentes e iluminó el lampadario.

La mayor parte de gastos generados por los fastos funerarios fueron asumidos por los jurados, quienes obtuvieron el placet del gobernador y de la junta de la Real Consignación ${ }^{69}$. En total, gastaron algo más de 443 libras mallorquinas en los pagos por el traba$\mathrm{jo}^{70}$, telas y vestimentas negras compradas al sastre Guillem Julià; más de 200 libras por la compra y alquiler de luminarias al droguero Miquel Esteva ${ }^{71}$; las mencionadas 740 libras de la erección del túmulo al escultor Giuseppe Dardanone, que firmó la obra; y, posiblemente, 450 pesos al artista Juan Francisco Aragón por el diseño de la capilla ardiente ${ }^{72}$.

67 Se utilizaron 524 cirios y 92 antorchas. Campaner, 1881, p. 508; ARM, AH 6155, sf.

${ }^{68}$ ACM, AC 1643, ff. 408v-409r.

69 ARM, EU 89, f. 217.

70 Los trabajos fueron coser cortinas, las lobas de los maceros, unir las telas a los bancos, tronas y columnas de la catedral y a las puertas de Cort y el Sindicato, las vestimentas de los tamborileros y trece capuces, incluyendo los de los reyes de armas, el del sepulturero y de varios sacerdotes.

${ }^{71}$ ARM, AH 6155, sf.

72 Este pago aparece en ARM, AH 6155, sf, junto al resto de gastos motivados por las exequias de Luis XIV, aunque en los textos sólo hay referencias al túmulo de Dardanone y no se menciona ninguna capilla ardiente. 
La revisión de cuentas conllevó problemas, por lo que los jurados pidieron a los síndicos clavarios que presentaran todos los documentos que acreditaran los pagos de los gastos de las exequias ${ }^{73}$. Por lo tanto, el gasto de cerca de 1.400 libras podría ser algo mayor ${ }^{74}$. El resto de instituciones que acudieron también hicieron algunos gastos. Por ejemplo, el Sindicat de Fora adquirió telas negras con la que hacer capas largas para vestir de luto, vestimenta que se trataba de una novedad para ese tipo de acto en Mallorca, sugerida por el Marqués de Lede ${ }^{75}$, compartiendo el gasto con la Universitat ${ }^{76}$, aunque los pagos se retrasaron varios años ${ }^{77}$. El capítulo catedralicio aportó una parte de las telas negras para cubrir la catedral, así como cera y aceite para la iluminación. Además de telas que ya poseían, pagaron 50 libras por bayeta negra y cera, cantidad decidida tras revisar lo que los canónigos habían pagado en las exequias de Felipe IV, María Luisa de Borbón, Mariana de Austria y Carlos $1{ }^{78}$.

Paralelamente, en el resto de las villas mallorquinas tenían lugar más exequias, siguiendo las órdenes del gobernador Marqués de Lede ${ }^{79}$. Por ejemplo, a la villa de Felanitx la orden llegó el 23 de noviembre. En la misiva se les conminaba, también, a celebrar el cumpleaños del rey. La celebración de las exequias constó de procesión con todas las autoridades locales y agentes reales, la erección de un túmulo con antorchas y cirios, se puso la marca de las flores de lis en la casa consistorial, se celebró una misa de réquiem y hubo un sermón del padre agustino Jaume Font, del convento agustino de Nuestra Señora de Itria del término de Palma (Xamena Fiol, 2016, pp. 126-127). En el caso de la ciudad de Alcudia, la orden gubernamental de celebrar las honras fúnebres se conoció el 21 de noviembre a través de su activo gobernador Antonio Gandolfo. Como en el caso de Felanitx, uno de los principales problemas fue el abono de los gastos de los oficios, el pago del túmulo pintado por Joan Baptista Colom y los vestidos de luto comprados al sombrerero Pere Antoni

${ }^{73}$ ARM, Suplicacions 83, ff. 48v-49r.

${ }^{74}$ A modo de referencia, podemos indicar que las exequias de Felipe IV supusieron para las arcas de la Universitat algo más de 4.000 libras mallorquinas. ARM, AH 6155, sf.

75 ARM, AH 4580, ff. 190r-190v. A los síndicos de manga y consejeros se les dieron 5 canas y media de bayeta negra. Al resto de miembros del Sindicat, síndicos, abogado, secretario, acompañantes y al capellán se les entregó alguna cantidad mayor.

${ }^{76}$ ARM, AH 4476, ff. 16v-17r. El gasto de las gramallas de los síndicos clavarios y los síndicos de manga ascendió a 400 libras. Se pagaron 120 libras al pelaire Pere Vicens Ramis, por la bayeta negra usada por los consejeros de la parte de la montaña. El resto de la tela, destinada para las capas de catorce consejeros y acompañantes, se compró a Gabriel Aguiló. AH 3705, f. 31v.

77 En marzo de 1716 se pagaron a Sebastià Juan, abogado del Sindicato, 25 libras por lo que había gastado en los lutos. En febrero de 1718 los dos síndicos clavarios aceptaron 25 libras de la cantidad que se le adeudaba por los lutos del rey Cristianísimo. ARM, AH 3705, f. 34r; ARM, AH 3706, f. 29v.

\footnotetext{
78 ACM, AC 1643, ff. 408v-409r.

79 ARM, AH 4580, f. 190r
} 
Guaita (Ventayol, 1982, p. 435). La diferencia respecto al resto de villas fue la impresión del libro de exequias que contenía la descripción de los actos y las exequias del padre Fullana, $\mathrm{SI}$, a propuesta del jurado Pere Antoni Roig, que había sido un destacado austracista, al resto del consejo el 21 de mayo de 1716 (Ventayol, 1982, p. 436).

\section{EL LIBRO DE EXEQUIAS}

El último acto, tanto en Palma como en Alcudia y algunas otras ciudades de la monarquía, fue la impresión del libro de exequias reales (Allo Manero et al., 2004, pp. 52-53; León Pérez, 2010, pp. 83-84). Fue en formato de folleto ilustrado, con la descripción de las funerarias, una reproducción del túmulo y una copia del sermón ${ }^{80}$. En el caso del texto palmesano se hicieron un gran número de $\operatorname{copias}^{81}$ y una de ellas pasó a formar parte de la biblioteca del rey de Francia ${ }^{82}$.

Los sermones de Ferrando, como el de Fullana en Alcudia, fueron impresos a principios de 1716, dada la voluntad de difusión de los promotores locales, quienes trataban de garantizar la estabilidad de la nueva planta de gobierno, asentarse como colaboradores del nuevo rey y mostrar su apoyo a la esperada alianza entre las coronas española y francesa ${ }^{83}$. Además, servían al propósito de representar a Felipe $V$ como garante de la memoria de su abuelo y continuador de su obra política. Un ejemplo de esta iniciativa real es la impresión de la descripción redactada por el Marqués de Villena, Juan Manuel Fernández Pacheco, mayordomo mayor, de las exequias celebradas por Luis XIV en Madrid en 1717, dos años después de su muerte, en las que incluyó un relato sobre la enfermedad del rey y la copia de la prédica del padre Castejón (Fernández Pacheco, 1717).

Todos los textos en Mallorca se redactaron en castellano (Garau Amengual, 1990; Calafat Vila, 2017). El público asistente y los potenciales lectores -la élite ciudadana, el funcionariado regio y las autoridades eclesiásticas- estaban ya familiarizados con el idioma, y se trataba, además, de un tipo de sermón que ya se había

${ }^{80}$ En la bibliografía aparece una recopilación de los libros de las exequias reales de Luis XIV impresos en ciudades de la monarquía que hemos podido conocer. En Francia se calcula que se imprimieron alrededor de cincuenta oraciones funerarias. Burke, 1995, p. 118.

${ }^{81}$ Actualmente se conservan ejemplares en casi todos los archivos históricos de las Baleares, además de en otras instituciones como la Biblioteca Nacional o la Biblioteca de Catalunya y en colecciones particulares.

${ }^{82}$ A mediados del siglo XVIII había un ejemplar, junto a otros sermones predicados a la muerte de Luis XIV en España en la biblioteca del rey de Francia. Bibliothèque du Roy, 1750, f. 238. Actualmente, hay un ejemplar en la Bibliothèque Nationale de France.

${ }^{83}$ Esta idea se transmitió en exequias celebradas en otros lugares. Serrano Martín, 2019, p. 103. 
predicado en esa lengua en otras ocasiones ${ }^{84}$. El hecho de que los jurados, tanto los del reino como los de la ciudad de Alcudia, redactaran e imprimieran los textos en castellano es un elemento más de la voluntad de las autoridades locales para que su mensaje llegara a la corte en un momento ${ }^{85}$, finales de 1715 y los primeros meses de 1716 , en que se quería negociar la transición hacia la nueva planta del gobierno del reino de Mallorca (Deyá Bauzá, 2018).

Los impresos incluyeron, además de la descripción de las exequias y el propio sermón, una portada. Incluía el escudo de la ciudad ${ }^{86}$, una dedicatoria del jesuita Ferrando a los jurados y las censuras eclesiásticas y civil de fray Jaume Malonda, fraile mínimo, del canónigo Pere Jeroni Penya y del fiscal del Real Patrimonio Josep Bassa.

Fray Jaume Malonda del convento de San Francisco de Paula que había sido vicario general de la provincia de Cataluña y predicador real, escribió la censura por orden del obispo. En su texto, trufado de citas a la Biblia, San Agustín, Casiodoro, San Gregorio Magno o Séneca, dedica encendidos elogios al contenido, a la forma y la capacidad de moderar la voluntad y los afectos del sermón escrito. El fraile no asistió a la ceremonia en la catedral (Ferrando, 1716, ff. 18-20), motivo por el que se hace eco de las repercusiones y del éxito que el predicador tuvo sobre el púlpito en el momento de pronunciar el sermón. Destaca, además de las alabanzas a Luis XIV, el uso de las fuentes bíblicas y de los escritos de los pontífices, con cuya autoridad el autor acreditaba todas las glorias del rey galo, consiguiendo acallar a quienes criticaban a su nieto, al tiempo que elogia de manera sucesiva la habilidad, artificio y eminencia que el orador despliega ante el texto.

Por orden del obispo Ezterripa, el doctor Pere Jeroni Penya Vaquer, canónigo de la catedral, examinador sinodal, vicegerente de la cancillería real y juez de competencias, compuso la segunda censura (Ferrando, 1716, ff. 21-27). Al contrario que en los textos de fray Malonda y del padre Ferrando, las principales fuentes que utilizó el canónigo fueron textos grecolatinos con citas a Suetonio, Virgilio, Persio, Horacio o Aristóteles. El escrito de Penya se inicia contraponiendo la alegría por tener a Felipe $\mathrm{V}$ como rey con la tristeza por el fallecimiento de Luis XIV y justificando

${ }^{84}$ En 1671, el visitador provincial aconsejaba a los jesuitas de Montesión de Palma sobre la lengua que se debía utilizar según la prédica: «Aunque ay muchas personas que entienden la lengua castellana, pero comúnmente no la entienden, de que se sigue frustrarse mucho del fruto que con los sermones se debía hazer. $Y$ así, los sermones de dominicas, adviento y quaresma predíquense en lengua natural. Algunos sermones panegíricos se podrán predicar en castellano» (AHN, Clero Jesuitas, Libros 747, f. 229r).

${ }^{85}$ Se trataba de una estrategia común en los territorios de la Monarquía para adecuarse al propósito y al público al que iban dirigido. Por ejemplo, para el caso de Sicilia y Nápoles, vid. Ciccarello, 2019, p. 8.

${ }^{86}$ En el caso de la oración de Alcudia la portada del sermón viene ilustrada con un sol, símbolo de Luis XIV, acompañado con la divisa «Nec pluribus impar». Fullana, 1716, f. 21. 
la obligación de los españoles de llorar la muerte del abuelo del rey, a pesar de que fuera extranjero, primero, por la grandeza del personaje y, segundo, por la relación familiar con su monarca. La segunda parte del texto alaba el sermón de Ferrando, especialmente, el efecto emocional provocado en el auditorio y la modestia de ceñirse a lo que escribieron los Papas sobre el rey.

La aprobación del poder real la redactó Josep Bassa, doctor en filosofía y en ambos derechos por la Universidad de Salamanca y abogado fiscal del Real Patrimonio, por comisión del doctor Miguel Malonda, presidente de la Real Audiencia y persona clave en la postguerra (Juan Vidal, 1979). El texto de Bassa se forma en base al halago de la figura y obra del sacerdote Ferrando y a la vinculación entre Luis XIV y Felipe V. A partir de textos grecorromanos ${ }^{87}$, el autor alaba la figura de Luis XIV, le representa como la definición del poder y del buen gobierno y sitúa a Felipe $\mathrm{V}$ como heredero de todas sus virtudes. En definitiva, las censuras eclesiástica y civil perseguían, además de evaluar el texto, mostrar la adhesión del reino hacia la dinastía Borbón y justificarla en base a argumentos políticos y religiosos, tal como desarrolla el padre Ferrando en su sermón.

\section{EL SERMÓN DEL PADRE FERRANDO. ESTRUCTURA}

El primer texto del padre Ferrando, con el que se inicia el libro, es la dedicatoria a las autoridades reales escrita en el colegio jesuita de Montesión, en enero de 1716, un mes después de la celebración de las exequias (Ferrando, 1716, ff. 15-17). Este pórtico, encabezado por el escudo del reino, sirve al autor para agradecer su elección como predicador y desarrollar la captatio benevolentiae. Tras esta breve presentación y el resto de textos intermedios a los que nos hemos referido, se inicia el sermón.

La imagen que va a presentar de Luis XIV en las exequias, así como en toda la monarquía, es la de gran gobernante, defensor de la fe y garante de su nieto en la Guerra de Sucesión (Assaf, 1999, pp. 150-154). Se trata de valores que se vinculan en ese momento, y se seguirían utilizando para describir al propio Felipe V (Castellano, 2004). El sermón de Ferrando se divide en cinco partes. La primera, introductoria, reflexiona sobre la figura del rey y sobre la muerte. Enmarca su discurso a partir del enunciado inicial, una cita del capítulo 29, versos 26 a 28 del Paralipómenos: Igitur David, Filius Isai,...mortus est in senectutem bona, plenus dierum et divitiis et gloria (Ferrando, 1716, ff. 33-37). La sentencia sirve al autor para presentar dos temas que enmarcan el conjunto del texto: la definición del buen rey y la buena muerte. Los tres siguientes apartados están dedicados a alabar cada una de las tres virtudes

${ }^{87}$ El autor cita a Ovidio, Horacio, Plinio, Cicerón, Casiodoro, Propercio, Quintiliano, Juvenal, Faecio, Aristóteles y Platón. Ferrando, 1716, ff. 28-31. 
principales que convertían al Rey Sol en el rey Luis el Grande. La primera es su labor de gobernante, que ocupa el capítulo titulado «Gran Rey» (Ferrando, 1716, ff. 37-44); la segunda, su capacidad como líder militar con el capítulo «Gran Capitán» (Ferrando, 1716, ff. 44-58); y, finalmente, su papel como campeón de la cristiandad con el apartado "Gran Católico», al que dedica la mayor extensión (Ferrando, 1716, ff. 49-72). El cierre del sermón es una reflexión sobre la muerte y la piedad divina.

\section{EL REY A TRAVÉS DEL SERMÓN}

El sermón se construye a partir de la proyección del rey como representación de las tres grandes virtudes que han de guiar la actividad regia: el rey como gobernante, como caudillo militar y como defensor de la fe. Con estos mismos atributos se describía al rey en el aparejo funerario de las exequias oficiales de Saint-Denis (Burke, 1995, p. 41). Para justificar esta lectura del reinado del monarca francés y transmitirla al auditorio durante las exequias y a los lectores potenciales del texto impreso, Ferrando hace referencias explícitas a hechos concretos. Apoya su discurso, al mismo tiempo, con referencias a documentos legales como privilegios, edictos o tratados internacionales, así como de las descripciones positivas que sobre algunas políticas del monarca hicieron los Papas en bulas y breves, en especial, de Clemente $\mathrm{XI}$, quien en ese momento ostentaba la mitra ${ }^{88}$. También, establece comparaciones con personajes conocidos por el auditorio como reyes bíblicos y de la Antigüedad. La comparación con figuras históricas es un recurso muy importante a lo largo del texto, iniciándose con la comparación entre el Luis XIV y el rey David. Esta figura era utilizada por los predicadores reales franceses ya en vida del monarca y el propio rey sentía alguna identificació ${ }^{89}$. Otras comparaciones se establecen con personajes bíblicos como Josafat de Judá y reyes de la Antigüedad, como Alejandro Magno en el aspecto militar, o Teodosio en lo religioso. Junto al aparato más reconocible como hechos políticos o las comparativas, también aparecen citas eruditas de autores, como el padre Cornelius; el padre Giovanni Paolo Oliva, gene-

${ }^{88}$ Se citan: Bula de Inocencio X «Zelo Domus Dei», 1650. Bula «Cum occasione» de 1653. Breve de 1653 «Ad Ludovicus XIV». Breves de Alejandro VII a los obispos franceses de 1661 y 1663. Bula "Regiminis Apostolicis» de 1665. Breve de Clemente IX: breve de 20 de septiembre de 1668. Breve de Inocencio XI a los cardenales del 8 de marzo de 1686. Breves a Luis XIV del 15 de noviembre de 1685 y de febrero de 1689. Breves de Clemente XI: breves de 20 de enero de 1683, 13 de febrero de 1701, 4 de octubre de 1701, 13 febrero de 1703. Bula "Unigenitus» de 8 de septiembre de 1713. En realidad, a la muerte del rey, la reacción del Papa Clemente XI fue de cierta frialdad. Assaf, 1999, p. 145. Sobre estas bulas, vid. Cornette, 2015, pp. 226-255.

${ }^{89}$ Burke, 1995, p. 30. Uno de los cuadros que decoraban la habitación privada del rey y que había sido elegido personalmente por él era «El rey David tocando el arpa» del pintor italiano Domenico Zampieri adquirido por Luis XIV en 1665 de la colección del cardenal Mazarino. 
ral de la Compañía de Jesús durante veinte años (1661-1681); Alfonso Fernández de Madrigal o Álvarez el Lusitano. Este despliegue de citas y referencias no tienen tan solo un valor ornamental. Demuestran la gran erudición por parte del orador de la actualidad histórica, nacional y extranjera, y evita, por tanto, plantillas sobre las que asentar su sermón acudiendo a fuentes y documentos de carácter específico. En este texto, la pluma de Ferrando defiende a la par historia y doctrina religiosa, asentando el discurso en una estructura tripartita, construido mediante la unión de un gran aparato retórico y un gran abanico de autoridades de carácter transversal.

En clave política, el texto persigue tres objetivos. El primero es presentar a Luis XIV como modelo de gobernante ideal en la paz y en la guerra (Assaf, 1999, pp. 150-154). El segundo objetivo se refiere a la política exterior. En este sentido, el autor busca justificar, fijar y hacer estimar el que será desde ese momento el entorno geopolítico en el que se moverá Mallorca: una alianza entre los borbones franceses y españoles, justificada y amparada por ser el servicio a la cristiandad, presentando a Luis XIV como el arquitecto de esta nueva alianza. El tercero se refiere a la política interior, en la que el autor resalta algunas actuaciones que deben ser integradas por la élite local, como la obligación de la nobleza a plegarse a la justicia real; la aceptación de los colaboradores foráneos del rey, como lo era en ese momento el gobernador de Mallorca; la importancia de la religiosidad a la hora del reparto de cargos o la eliminación de rencillas internas entre la nobleza (Ferrando, 1716, ff. 40-43).

Como en el resto de obras oficiales que tratan la figura de Luis XIV en esta época, se le retrata como ejemplo del buen gobierno (Ferrando, 1716, ff. 37-44). Ferrando destaca los esfuerzos del rey por mejorar el funcionamiento de la justicia, así como la supervisión y regulación de las actuaciones de los parlamentos y agentes políticos locales a través de políticas activas como la elección de ministros competentes, el uso adecuado de las finanzas o la creación de un código de leyes civiles y criminales. En este pasaje hay varios mensajes dirigidos directamente a la élite mallorquina. Para describir la política francesa, Ferrando pudo acceder a textos de carácter legal como los edictos de Nantes de Enrique IV y Luis XIII y, también a las ordenanzas de derecho civil y edictos de Luis XIV. Entre este tipo de documentos, el jesuita cita las ordenanzas dadas en Saint Germain-en-Laye de 1667 y 1670 y diversos edictos sancionados por el rey entre 1653 y 1665 que habían sido editados en Italia por Bernini y Morelli, además de otras obras francesas.

En segundo lugar, el rey Luis XIV es presentado como continuador de los grandes reyes guerreros de la historia, bíblicos y clásicos (Ferrando, 1716, ff. 44-55). El jesuita loa sus victorias en las guerras del siglo XVII. Son significativas las palabras del prólogo de la obra Ferrando, en las que recuerda la conquista de Palma como la última gran victoria del rey francés (Ferrando, 1716, f. 5). En la narración de algunos pasajes históricos, además, de las fuentes legales como los textos de las paces de Münster de 1643 y de Ryswick de 1697, utilizó la obra Historia del Emperador 
Leopoldo o Historia de la vida y los hechos del emperador Leopoldo I de Galeazzo Gualdo, publicada en tres tomos entre 1666 y $1674^{90}$.

Finalmente, el aspecto que más destaca de la vida de Luis XIV, y con el que se cierra el discurso, es su papel como defensor de la Cristiandad en toda Europa (Ferrando, 1716, ff. 55-72). El autor mallorquín recuerda como momentos significativos de la política religiosa del rey Cristianísimo la revocación en 1685 de los edictos de Nantes y de Nimes y la lucha contra el jansenismo. Entre las políticas internas de fomento del catolicismo también se mencionan las campañas misionales llevadas a cabo en Francia y, desde su condición de jesuita, destacaba el apoyo dado por el rey a la Compañía de Jesús con la fundación y dotación de siete colegios, mencionando los de los puertos de Brest y Tolón donde debían formarse los capellanes para las armadas y navíos mercantes (Ferrando, 1716, f. 50). La protección de la fe católica por parte del rey no se circunscribe sólo a Francia. El rey es descrito como campeón de la cristiandad y, por lo tanto, como la contraparte del pretendiente Carlos III, monarca defendido por luteranos, anglicanos y calvinistas, contra quienes se enfrentó durante su reinado. Entre las actuaciones de defensa del catolicismo en Europa, se relata la generosa ayuda prestada por Luis XIV al rey Jacobo II Estuardo para que recobrara la corona británica y mejorara la situación del cristianismo en las islas y, también, la participación francesa en la guerra contra el Imperio Otomano en las batallas de San Gotardo (1665) y Candía (1668) ${ }^{91}$. Ferrando alaba la política del rey precisamente por eso, por haberse guiado siempre por la religión y no por razones de estado. Así, el final de los edictos de Nantes y Nimes supuso reforzar los ejércitos enemigos y debilitar los suyos propios con la llegada de emigrantes hugonotes, entre ellos militares como el Duque de Schomberg, a territorios calvinistas y protestantes. Lo que unido al apoyo prestado a Jacobo III en su reclamación del trono inglés y escocés, fortalecía la alianza entre holandeses e ingleses y les daba más motivos para posicionarse en la sucesión a la corona española junto al archiduque Carlos, quien no rechazó esos apoyos, demostrando, al contrario que Luis XIV, que su defensa del catolicismo se supeditaba a sus intereses políticos. En este punto del discurso queda claro que el padre Ferrando y el entorno local con el que debió comentar el contenido del texto conocían bien y tuvieron acceso a los principales argumentos de la propaganda proborbónica.

90 Esta obra histórica tuvo una gran difusión. Copias de este libro llegaron hasta el Caribe a principios del siglo XVIII. Márquez, 2010, p. 53.

${ }^{91}$ En esta descripción, Ferrando utiliza la Historia del reinado de Leopoldo I como fuente. El autor la describe como una obra antifrancesa, el hecho de que en ella se alabara el coraje francés en la batalla contra los turcos permite al autor señalar la veracidad de sus afirmaciones sobre el rey como campeón de la cristiandad. Ferrando, 1716, ff. 55-56. 
Como episodio final de la semblanza regia, el autor señala en dos pasajes de la obra la buena muerte del rey tras solicitar y recibir la confesión y la extremaunción ${ }^{92}$. Se trata, en conclusión, de un conjunto de imágenes y juicios sobre el rey Sol que se ajustan a los discursos fúnebres leídos en Madrid (Castejón, 1716) y París (Macé, 2015; Cornette, 2015, pp. 38-52; Assaf, 2018). Al mismo tiempo que se atendía a las circunstancias de un contexto local marcado por la posguerra, la nueva situación internacional y la incertidumbre ante la futura organización política de cuño borbónico.

\section{CONCLUSIONES}

La muerte de Luis XIV y los acuerdos de Utrecht abrían una nueva situación. Francia, el país que fue el principal enemigo durante todo el siglo XVII para una buena parte de los españoles durante la Guerra de Sucesión, dejaba de serlo. Esta nueva perspectiva fue muy sentida en un territorio como Mallorca, ya antes del conflicto sucesorio. Se trataba de un territorio fronterizo con Francia, que se vio sometido a una gran tensión dados los rumores continuos de un plan de ocupación o de bombardeo de las islas por Luis XIV. Esto motivó que una parte de la población hiciera de la depredación de navíos mercantes provenzales y de la guerra con Francia, como también del comercio con el enemigo, una parte importante de su modo de vida.

El sermón de Ferrando es un episodio local, significativo, que se ha de relacionar con el fin de la guerra y el intento de las élites locales por situarse dentro del entramado institucional que se estaba creando en ese mismo momento durante el diseño de los decretos de nueva planta. A su vez, las palabras del jesuita Ferrando, así como la acción de las autoridades locales, están conectadas con la imagen que el Rey Sol quiso crear de sí mismo en su reinado y, también, con las honras fúnebres celebradas en Madrid por la corte de Felipe V. En definitiva, caracterizar a Luis XIV como buen gobernante, caudillo victorioso y campeón de la cristiandad

Las autoridades locales, que habían planificado, costeado y, junto al capítulo catedralicio, ejecutado las honras fúnebres, consiguieron demostrar al retornado monarca la adhesión del reino a la nueva planta de gobierno. Todo ello se consiguió a partir de la difusión de estos actos, la negociación política en la corte, la intervención del caballero d'Asphelt o la celebración del cumpleaños real y del nacimiento del príncipe. Las celebraciones se utilizaron, también, como un intento para mentalizar a la población mallorquina, en su mayoría señalada como aus-

92 Para describir la enfermedad del rey hizo uso del impreso Ex fidedignis scriptis Luthetiam missis et typis. In Hispania datis. 
tracista ${ }^{93}$, del signo de los nuevos tiempos. También se pretendía contrarrestar el sentimiento de derrota en el conflicto y evitar la notoriedad de episodios típicos de un momento de postguerra como el exilio ${ }^{94}$, la publicación de propaganda de los vencidos a favor del pretendiente Carlos ${ }^{95}$ o detenciones de antiguos austracistas $^{96}$.

Los elogios fúnebres a Luis XIV significaron difundir y construir la imagen de Felipe $V$, legitimar la dinastía Borbón a partir de la exaltación de las armas y la defensa de la religión y escenificar la nueva alianza franco-española que ya empezaba a sentirse en la propia isla ${ }^{97}$. De esta manera, a lo largo del siglo XVIII, Luis XIV se convertiría en una figura elogiada en España. Se tradujeron biografías $^{98}$, a quien se presentó como padre del gobierno borbónico (García Cárcel, 2002, p. 112) y espejo de gobernantes (Mínguez, 2016, p. 419), y a quien, incluso, se le llegó a convertir en protagonista de una obra de teatro en castellano escrita por el catalán Comella, uno de los principales autores de teatro de su época (Comella, 1790). La redención de Luis XIV entre el público español se había completado.

93 Morro Marcé, 2015.

${ }^{94}$ Sobre el exilio de los mallorquines austracistas, vid. Alcoberro, 2018.

95 A finales de 1717 se investigó la aparición de unos versos dedicados al ya emperador Carlos VI por sus victorias en la guerra contra el Imperio Otomano y contrarios a los filipistas mallorquines. Se habían pegado en uno de los muros interiores de la catedral y se distribuyeron copias en el templo que llegaron a manos de sacerdotes y caballeros de la ciudad. Se acusaba de su autoría o divulgación al beneficiado en la seo Gabriel Pastor. El texto decía: «Viva l’Emperador/ Viva la sua fortuna/Viva son gran poder/Contra la mitja lluna/Rei sobre tots los reis/Que no feu animares/de la gran victòria/de Sardenya com serà al revés/Com va botiflers, tort/Salas serà al revés» (ADM, 018-002-018). Al final de la guerra nueve clérigos de la catedral fueron expulsados de la isla por su compromiso austracista. Juan Vidal, 2018, p. 434.

96 Durante el mes de diciembre de 1715 se distribuyeron pasquines contra el gobierno. El culpable fue obligado a pasear por la ciudad en un jumento con un letrero que decía: «Per publicador de veus sediciosas i tumultuarias». Campaner, 1881, p. 508. Ese mismo año se investigaron a algunos sospechosos de ser austracistas. Por ejemplo, en el convento de los carmelitas se inculpó a dos frailes por utilizar el refectorio para hacer plegarias favorables al ejército de Carlos III y acusar a sus compañeros de filipistas. ARM, Not. R 187, ff. 181-192.

${ }_{97}$ En 1717 la colonia mercantil francesa residente en Palma era ya muy numerosa contando con un cónsul en la persona de Joseph Nieulon. Bibiloni Amengual, 1995. Sobre el cónsul Nieulon vid. Mézin, 1997, pp. 464-466.

98 En 1735 el librero de Sevilla Raimundo Ferrús publicó la traducción castellana de la biografía de Luis XIV escrita por el jesuita francés Gabriel Daniel. Daniel, 1735. 


\section{BIBLIOGRAFÍA}

Impresos

Alcalá Guiribari, J. (1717). Motivos de dolor que en las funerarias tiernas exequias del siempre augusto señor invicto cristianísimo rey de Francia Luis XIV. Predicó el Dr. D. Joseph de Alcalá y celebró la Santa Iglesia de Valladolid, cabeça del obispado de Michoacán el día 14 de noviembre de 1716. Ciudad de México: Imprenta de los herederos de la viuda de Francisco Rodríguez Lupercio.

Álvarez de Toledo Pellicer, I., Marqués de Salmerón (1701). Despedimiento que el leal afecto del Marqués de Salmerón discurre avrà hecho el Christianíssimo Luis el Grande de nuestro Católico Monarca D. Phelipe Quinto (que Dios guarde) y le dedica à su persona con este Soneto. Barcelona: Imprenta Cormellas.

Andosilla, J. (1716). Augustas memorias erigidas a la gloriosa fama del Cristianísimo Rey de Francia, Luis XIV, el Grande, en el magnífico funeral que hizo la muy noble, muy fiel y siempre augusta ciudad de Zaragoza a quién dedica su descripción. Zaragoza: Imprenta de Pascual Bueno.

Bibliothèque du Roy (1750). Catalogue des libres imprimés de la Bibliothèque du Roy. Belles Lettres, I. París: Imprimerie Royale.

Bracamonte, J. de D. (1717). Espejo de príncipes, propuesto, no menos al desengaño de caducas glorias que a la imitación de gloriosas virtudes en las suntuosas exequias que la imperial corte mexicana celebró al Cristianísimo Rey de Francia Luis Decimo Quarto el Grande. México: Imprenta de los herederos de la viuda de Miguel de Rivera.

Campaner Fuertes, Á. (1881). Cronicón Maioricense. Palma: Imprenta Colomar.

Casal Montenegro, J. A. (1716). Victima dolorosa, clamor lamentable, expresión fina del lealísimo afecto con que la ilustre ciudad de Málaga solemnizó las reales exequias del cristianísimo rey, el señor Don Luis XIV. Málaga: Imprenta de Juan Vázquez Piedrola.

Castejón, A. (1716). Luis el Grande, oración fúnebre del muy alto, muy poderoso y muy excelente príncipe Luis XIV, Rey Cristianísimo de Francia, Ilamado comúnmente el Grande. Madrid: Imprenta de Diego Martínez. 
Comella, L. F. (1790). Comedia heroica nueva en tres actos: Luis XIV el grande. Barcelona: Juan Francisco Piferrer.

Daniel, G. (1735). Compendio de los sucesos del reynado de Luis XIV el Grande, rey de Francia, que con título de fastos o diario histórico compuso en idioma francés el célebre escritor el P. Gabriel Daniel, de la compañía de Jesús, traducido en castellano y dedicado a la Magestad del señor Don Felipe V, rey de España, por Raimundo Ferrús, su librero en Sevilla. Sevilla: Imprenta de Juan Francisco Blas de Quesada.

Fernández Pacheco, J. M. (1717). Relación de las reales exequias que se celebraron por el Serenísimo señor Luis XIV el Grande, rey Cristianísimo de Francia, abuelo de la Magestad del rey nuestro señor, Dios le guarde. Madrid: Diego Martínez Abad.

Ferrando, J. A. (1716). Elogio fúnebre a las gloriosas memorias del Serenísimo Señor Luis XIV el grande, rey cristianísimo de Francia. En las reales funerales honras que en obsequio de SM celebró la ciudad y reino de Mallorca el día 12 de diciembre del año 1715. Palma: Imprenta Capó.

Fullana, B. A. (1716). Oración fúnebre en las solemnísimas exequias con que la fidelísima ciudad de Alcudia en el Reino de Mallorca lloró la muerte del Sol de la Francia, el Insigne rey Luis XIV. Palma: Imprenta Frau.

Haro, J. A. (1716). Panegyrico funeral en las reales exequias que hizo la Universidad de Salamanca en su real capilla el día 23 de diciembre de 1715 al sr. Rey cristianísimo de Francia Luis XIV el grande. Salamanca.

Garau, F. (1691). La fe triunfante en cuatro autos. Palma: Imprenta Guasp.

Presentación, J. (1716). Sermón panegírico, fúnebre predicado en las honras que a la muerte del cristianísimo rey Luis XIV de Francia, abuelo de nuestro católico monarca $D$. Felipe $V$, celebró el ilustre y venerable clero de la ciudad de Carmona el día 26 de noviembre de 1715. Sevilla: Imprenta de Juan de la Puerta.

Zúñiga Ribera, L. (1716). Oración fúnebre en las reales lúgubres honras que las dos comunidades, cabildo y ciudad de Ávila, consagraron el día 16 de enero de 1716 por la inmortal memoria del serenísimo señor Luis XIV el grande, rey cristianísimo de la Francia, amante abuelo de nuestro amado dueño, el señor Felipe $V$ el animoso, rey de las Españas. Salamanca: Imprenta de Eugenio Antonio García. 


\section{Estudios}

Alabrús, R. M. (2014). El clero catalán en la Guerra de Sucesión. Estudis, Revista de Historia Moderna, 40, pp. 213-233.

Albareda, J. (2000). Felip V i Catalunya, Manuscrits, 18, 2000, pp. 29-40.

Albareda, J. (2001). Cataluña y Felipe V: razones de una apuesta. En P. Albadalejo (ed.), Los Borbones. Dinastía y memoria en la España del siglo XVIII (pp. 303330). Madrid: Marcial Pons.

Alcoberro, A. (2018). Mallorquins i eivissencs a l'exili austriacista. En M. J. Deyá Bauzá (coord.), 1716. El final del sistema foral de la Monarquía Hispánica (pp. 229-242). Lleonard Muntaner: Palma.

Allo Manero, M. A., Esteban Llorente, J. F. (2004). El estudio de las exequias reales de la monarquía hispana: siglos XVI, XVII y XVIII. Artigrama, 19, pp. 39-94.

Alloza Aparicio, A. (2006). Guerra económica y comercio europeo en España. 16241674. Las grandes represalias y la lucha contra el contrabando. Hispania, 219, pp. 227-280. https://doi.org/10.3989/hispania.2005.v65.i219.163.

Álvarez López, A. (2007). Los negocios de Luis XIV en Madrid: la acción de sus embajadores en la corte madrileña. Revista de Historia Moderna. Anales de la Universidad de Alicante, 25, pp. 179-206. https://doi.org/10.14198/ RHM2007.25.07.

Álvarez López, A. (2008). La fabricación de un imaginario: los embajadores de Luis XIV y España. Madrid: Cátedra.

Assaf, F. (1999). La mort du roi: une thanatographie de Louis XIV. Tubinga: Gunter Narr Verlag.

Asssaf, F. (2018). Quand les rois meurent: les journaux de Jacques Antoine et de Jean et François Antoine et autres documents sur la maladie et la mort de Louis XIII et de Louis XIV. Tubinga: Gunter Narr Verlag.

Bada Elias, J. (2007). La postura de la Companyia de Jesús davant la Guerra de Successió (1700-1718). En M. Morales (coord.), L'aposta catalana a la Guerra de Successió (1705-1707). Barcelona: Generalitat de Catalunya. 
Barceló Crespí, M. (2018). Algunes dades sobre exèquies reials a Mallorca (14161516). BSAL, 74, pp. 269-290.

Bernardo Ares, J. M. (2008). Luis XIV, rey de España. De los imperios plurinacionales a los estados unitarios. Madrid: lustel.

Bernardo Ares, J. M. (2011). De Madrid a Versalles: la correspondencia bilingüe entre el Rey Sol y Felipe V durante la Guerra de Sucesión, Barcelona: Planeta.

Bernardo Ares, J. M. (2015). Luis XIV y Europa. Madrid: Síntesis.

Bibiloni Amengual, A. (1995). El comerç exterior de Mallorca: homes, mercats $i$ productes d'intercanvi (1650-1720). Palma: El Tall.

Bonnet, P. (2015). Une poétique politique de l'événement: formes et sens des poèmes satiriques diffusés à la mort de Louis XIV. Dix-Septième Siècle, 269, pp. 599-622. https://doi.org/10.3917/dss.154.0599.

Borrereguero Beltrán, C. (2003). Imagen y propaganda de guerra en el conflicto sucesorio. Manuscrits, 21, pp. 95-132.

Bosch Juan, M. (2003). Litúrgia i propaganda política als funerals regis a Mallorca. En Festa i cerimònia a Palma (pp. 9-50). Palma: Ajuntament de Palma.

Bover Rosselló, J. M. (1868). Biblioteca de escritores baleares, I. Palma: Imprenta Gelabert.

Bunes Ibarra, M. A. (2018). El cambio dinástico en la política de Berbería: Orán 1732. En M. J. Deyá Bauzá (coord.), 1716. El final del sistema foral de la Monarquía Hispánica (pp. 171-185). Palma: Lleonard Muntaner.

Burke, P. (1995), La fabricación de Luis XIV. Nerea: Madrid.

Burrieza Sánchez, J. (1998). Ciudades, misiones y misioneros jesuitas en la España del siglo XVIII. Revista de Historia Moderna, 17, pp. 75-107.

Burrieza Sánchez, J. (2004). Frailes y predicadores en la Catedral de Valladolid. Investigaciones Históricas, 24, pp. 77-104.

Calafat Vila, R. (2017). La regulación de la enseñanza en la Mallorca del siglo XVIII. Dieciocho. Hispanic Enlightment, 40, pp. 285-312. 
Cassanyes Roig, A. (2017). La Universidad Luliana de Mallorca y la Guerra de Sucesión. En J. E. Hortal Muñoz et al. (dirs.), La enseñanza de las humanidades y las ciencias sociales a través del mundo digital (pp. 157-195). Ediciones Digitales ED.

Castellano, J. L. (2004). La exaltación dinástica. En E. Serrano Martín (ed.), Felipe $V$ y su tiempo: congreso internacional (I, pp. 933-946). Zaragoza: Instituto Fernando el Católico.

Castellanos Losada, B. (Coord.). (1865). Biografía eclesiástica completa, vol. 25, Madrid: Real Academia de Arqueología y Geografía.

Ciccarello, D. (2019). Imprenta y poder en el Siglo de Oro. Relaciones y avisos sobre las fiestas reales entre Palermo y Nápoles. Memoria y Civilización, 22, pp. 1-40. https://www.unav.edu/publicaciones/revistas/index.php/myc/article/ view/37143/32205. https://doi.org/10.15581/001.22.009.

Cornette, J. (2015). La mort de Louis XIV. Apogée et crépuscule de la royauté (1er septembre 1715). París: Gallimard.

Deyá Bauzá, M. J. (2007). Les Balears durant els inicis de la Guerra de Successió; fractura social i projecte polític? En M. Morales et al (eds.), L'aposta catalana a la Guerra de Successió (1705-1707) (pp. 147-164). Barcelona: Generalitat de Catalunya.

Deyá Bauzá, M. J. (2010). Repercussions del Tractat dels Pirineus a les Illes Balears. En O. Janer (ed.), Del Tractat dels Pirineus a I'Europa del segle XXI: un model en construcció? (pp. 55-66). Barcelona: Museu d'Història de Catalunya.

Deyá Bauzá, M. J. (2014). Entre la guerra i el dia a dia: Mallorca de juliol de 1713 a juliol de 1715. En J. Albareda y A. Alcoberro (eds.), Els tractats d'Utrecht. Clarors i foscors de la pau. La resistència dels catalans (pp. 415-425). Barcelona: Museu d'Història de Catalunya.

Deyá Bauzá, M. J. (2018). La génesis del Decreto de Nueva Planta de Mallorca y los diputados del reino en la corte de Felipe V (1715-1717). En J. M. Deyá Bauzá (coord.), 1716. El final del sistema foral de la Monarquía Hispánica (pp. 189228). Palma: Lleonard Muntaner.

Díaz Díaz, G. (1988). Hombres y documentos de la filosofía española, vol. 3. CSIC: Madrid. 
Egido López, T. (2004). Los jesuitas en España y en el mundo hispánico. Madrid: Marcial Pons, 2004.

Escamilla González, I. (2011). Los intereses malentendidos. El consulado de comerciantes de México y la Monarquía Española. 1700-1739. Ciudad de México: UNAM.

Espino López, A. (2008). La presión francesa sobre las Baleares durante el reinado de Carlos II. 1673-1689. Hispania, 68, pp. 107-150. https://doi.org/10.3989/ hispania.2008.v68.i228.76.

Espino López, A. (2010). En la perifèria dels regnes perifèrics. Palma: Lleonard Muntaner.

Fajarnés, E. (1898). Santa Bárbara, patrona de Palma (siglo XVIII). BSAL, 7, pp. 222226.

Ferrer Flórez, M. (2004). Notas y edición. Historia del colegio de nuestro padre San Ignacio de Loyola, fundado en la villa de Pollensa del reyno de Mallorca a 19 de junio de 1688. BSAL, 60, pp. 51-116.

Garau Amengual, J. (1990). El primer siglo de la literatura castellana en Mallorca (1589-1688). Palma: IEB.

Garau Amengual, J. (2018). El sermón a las honras fúnebres del padre Juan Eusebio Nieremberg (1565-1658). Una hagiografía predicada al servicio de la exaltación de la Compañía de Jesús. En J. Garau Amengual (ed.), Religión, política y moralidad en el Barroco. La predicación en la España del siglo XVII (pp. 49-77). Madrid-Oporto: Sindéresis.

García Cárcel, R. (2002). De los elogios a Felipe V. Madrid: Centro de Estudios Políticos y Constitucionales.

García Pérez, F. J. (2014). El cabildo catedralicio de Mallorca (1700-1750). Tiempos Modernos. Revista electrónica de historia moderna, 29(1).

García Pérez, F. J. (2017). La oratoria sagrada como arma política: los predicadores reales de Juan José de Austria. Obradoiro de historia moderna, 26, pp. 237-265. https://doi.org/10.15304/ohm.26.4314. 
García Pérez, F. J. (2019). Juan Rodríguez Coronel. Un predicador jesuita en la corte de Carlos II. Madrid-Oporto: Sindéresis.

Hersant, M. (2015). Louis XIV: la mort à vif. Dix-septième Siècle, 269, pp. 583-588. https://doi.org/10.3917/dss.154.0583.

Juan Vidal, J. (1979). Informe y descripción de las instituciones de gobierno y de administración de justicia enviada a Felipe V por D. Miguel Malonda. Fontes Rerum Balearium, III, pp. 267-282.

Juan Vidal, J. (2014). El austracismo en el Reino de Mallorca. Cuadernos dieciochistas, 24, pp. 165-193. https://doi.org/10.14201/cuadieci201415165193.

Juan Vidal, J. (2018). Las Baleares en la Guerra de Sucesión a la corona de España. En M. J. Deyá Bauzá (coord.), 1716. El final del sistema foral de la Monarquía Hispánica (pp. 397-434). Palma: Lleonard Muntaner.

León Pérez, D. (2010). Las exequias reales en Madrid durante el primer tercio del siglo XVIII: corte y villa. León: Universidad de León.

León Pérez, D. (2012). Los sermones simbólicos y los jeroglíficos literarios de las exequias fúnebres: la defensa de la legitimada de Felipe V. En A. Baraibar y M. Insúa (eds.), El universo simbólico del poder en el Siglo de Oro (pp. 143-157). Nueva York-Pamplona: Instituto de Estudios Auriseculares (IDEA)/ Servicio de Publicaciones Universidad de Navarra.

Llabrés Bernal, J. (1935). Índice de algunos papeles referentes a Baleares que se conservan en el Archivo Histórico y Biblioteca Nacional de Madrid. BSAL, 26, pp. 54-84.

Llabrés Bernal, J. (1993). Les pintures decoratives de Can Salas major. Una aproximació a Josep Dardanon i a l'art del segle XVIII a Mallorca. Quaderns $A R C A, 12$, pp. 33-44.

López Nadal, G. (1986). El corsarisme mallorquí a la Mediterrània occidental: un comerç forçat (1652-1684). Palma: Conselleria d'Educació i Cultura.

López Nadal, G., Morey Tous, A. (2018). El corso como servicio a la Corona y oportunidad de negocio para los particulares. La escuadra de Mallorca (16601684). Revista de Historia Industrial, 73, pp. 11-42. 
Luengo, P. (2012). En nombre del rey. Exequias en Goa y Manila a mediados del siglo XVIII. Potestas, 5, pp. 219-234. https://doi.org/10.6035/Potestas.2012.5.9.

Márquez Macías, R. (2010). La actividad cultural en los puertos del Caribe en el siglo XVIII. El caso del comercio de libros. En J. Elías Caro y A. Vidal Ortega (eds.), Ciudades portuarias en la Gran Cuenca del Caribe: visión histórica, Barranquilla: Universidad del Norte.

Martín Corrales, E., López Nadal, G. (2018). Entre la iniciativa privada y el escalafón de la Armada: los corsarios de las Baleares. En M. J. Deyá Bauzá (coord.), 1716. El final del sistema foral de la Monarquía Hispánica (pp. 311-333). Palma: Lleonard Muntaner.

Martínez Gil, F. (2011). Los sermones como cauce de propaganda política: la Guerra de Sucesión. Obradoiro de Historia Moderna, 20, pp. 303-336. https://doi. org/10.15304/ohm.20.16.

Martínez Peñas, L. (2007). El confesor del rey en el Antiguo Régimen, Madrid: Editorial Complutense.

Martínez Ramos, A. (2011). El papel de la fiesta política en el cambio de dinastía durante el primer reinado de Felipe V: el caso de Granada. Revista del CEHGR, 23, pp. 129-143.

Macé, S. (2015). La grandeur à l'épreuve de la mort: à propos de l'oraison funèbre de Louis XIV par Massillon. Dix-Septième Siècle, 269, pp. 623-632. https://doi. org/10.3917/dss.154.0623.

Mézin, A. (1997). Les consuls de France au siècle des Lumières (1715-1792). París: Ministère des Affaires étrangères.

Mínguez, V. (1994). La imagen de Luis XIV en sus exequias novohispanas: la flor francesa y el espejo de príncipes. En D. Ortega Saavedra et alii (eds.), Tiempos de Latinoamérica (pp. 5-32). Castellón: Universitat Jaume I.

Mínguez, V. (2016). Reyes enfermos e imperio renovado. Las muertes de Felipe IV, Carlos II, Luis XIV, Luis I y Felipe V en la Nueva España (1665-1746). Romance Notes, 56(3), pp. 413-423. https://doi.org/10.1353/rmc.2016.0043.

Montaner Alonso, P. (1990). Una conspiración filipista. Mallorca 1711. Palma: Guillermo Canals. 
Montaner, P., Massot, M. J. y Seguí, J. (2006). La Guerra de Successió a Mallorca. 1700-1715. Una aproximació als protagonistes. Palma: Ajuntament de Palma.

Morgat, A. et al. (2010). L'Atles de les Illes Balears de Lluis XIV. Palma: Olañeta.

Morro Marcé, M. (2015). Fora botiflers, fora galls! La Guerra de Successió a les Illes Balears. Palma: Lleonard Muntaner.

Negredo del Cerro, F. (2002). La palabra de Dios al servicio del Rey: la legitimación de la Casa de Austria en los sermones del siglo XVII. Criticón, 84-85, pp. 295311.

Negredo del Cerro, F. (2012). Liturgia y retórica. La real capilla desde la historia cultural. En A. De Vicente Delgado y P. Tomás (coords.), Tomás Luis de Victoria y la cultura musical en la España de Felipe III (pp. 63-92). Madrid: Centro de Estudios Europa Hispánica.

Obrador Vidal, B. (2011). 450 años de Historia del Colegio de Montesión. Apuntes cronológicos y documentación histórica, 3 vols. Asociación de Antiguos Alumnos del Colegio de Montesión: Palma.

Oliver Moragues, M. (1997). Mallorquines obispos de Malta y grandes priores de San Juan de Jerusalén. MRAMEGH, 7, pp. 7-22.

Ortega Gato, E. (1953). Palencia en la Guerra de Sucesión. Publicaciones de la Institución Tello Téllez de Meneses, 10, pp. 5-53.

Pascual Chenel, A. (2014). De Austrias a Borbones: retrato, poder y propaganda en el cambio de siglo; continuidad o fractura. En M. Torres Arce y S. Truchuelo García (eds.), Europa en torno a Utrecht (pp. 253-286). Santander: Universidad de Cantabria.

Pascual Ramos, E. (2013). Poder y linaje durante la guerra de Sucesión en el reino de Mallorca. Palma: El Tall.

Pascual Ramos, E. (2016). El Decret de Nova Planta a Mallorca. Temps del Leviatán. Palma: Lleonard Muntaner.

Pérez Martínez, L. (1985). Un nuevo texto acerca de un atentado contra el culto de Ramón Llull (1699). BSAL, 41, pp. 333-359. 
Pérez Picazo, M. T. (1996). La publicística española en la Guerra de Sucesión. Madrid: CSIC.

Quijano Álamo, D. (2014). El cabildo de la iglesia catedral de Palencia: canónigos y predicadores del sermón fúnebre regio durante el setecientos. Estudios Humanísticos. Historia, 13, pp. 97-121. https://doi.org/10.18002/ehh. v0i13.1588.

Ramis Barceló, R. (2013). El proceso inquisitorial al catedrático lulista Sebastián Riera (1661-1668). Revista de la Inquisición, 17, pp. 107-139.

Ramis Barceló, R. (2014). Las cátedras suaristas de la Universidad Luliana y Literaria de Mallorca (1692-1767). Archivum Historicum Societatis lesu, 83, pp. 399-425.

Ramis Barceló, R. (2018). La Guerra de Sucesión y la extinción del Reino de Mallorca en la Universidad Luliana. En M. J. Deyá Bauzá (coord.), 1716. El final del sistema foral de la Monarquía Hispánica (pp. 357-369). Palma: Lleonard Muntaner.

Ramis Barceló, R., Cassanyes Roig, A. (2014). Los grados en teología suarista en la Universidad Luliana y Literaria de Mallorca (1694-1771). MRAMEGH, 24, pp. 55-88.

Rodríguez Moya, I. (2015). Un archipiélago para los Borbones: fiestas regias en Mallorca en el siglo XVIII. Espacio, tiempo y forma. Serie VII Historia del Arte, 3, pp. 311-342. https://doi.org/10.5944/etfvii.3.2015.14003.

Santamaría Arández, A. (1989). Nueva Planta de gobierno de Mallorca. Enfiteusis y Real Capbrevación. Palma: Consell de Mallorca.

Sebastián López, S. (1973). Arquitectura mallorquina moderna y contemporánea. Palma: Estudio General Luliano.

Serrano Martín, E. (2014). Las exequias de María Luisa Gabriela de Saboya en Aragón (1714). Política y religión en los discursos funerales. E-Spania, 17. https:// journals.openedition.org/e-spania/23334?lang=en. https://doi.org/10.4000/ e-spania.23334.

Serrano Martín, E. (2019). Ceremonias y cultura política en el Reino de Aragón con los primeros Borbones (1700-1746). Magallánica, 5(10), pp. 79-109. http:// fh.mdp.edu.ar/revistas/index.php/magallanica/article/view/3606. 
Soto Caba, V. (1989). La configuración de un modelo. Los catafalcos madrileños durante el reinado de Felipe V. Espacio, Tiempo y Forma. H. $\underline{a}$ del arte, 2, pp. 169-195. https://doi.org/10.5944/etfvii.2.1989.2142.

Vaquer Bennàsser, O. (2017). El comerç marítim de Mallorca a la primera meitat del segle XVII. Palma: El Tall.

Varela, J. (1990). La muerte del rey: el ceremonial funerario de la monarquía española (1500-1885). Madrid: Turner.

Ventayol Suau, P. (1982). Historia de Alcudia, vol. 1. Palma: Ripoll.

Voltaire (1954). El siglo de Luis XIV. Ciudad de México: Fondo de Cultura Económica.

Xamena Fiol, P. (2016). Felanitx en el segle XVIII, vol. 1. Felanitx: Ajuntament de Felanitx. 